\title{
The Structures, Molecular Orbital Properties and Vibrational Spectra of the Homo- and Heterodimers of Sulphur Dioxide and Ozone. An Ab Initio Study
}

\author{
Thomas A. Ford (D)
}

Citation: Ford, T.A. The Structures, Molecular Orbital Properties and Vibrational Spectra of the Homo- and Heterodimers of Sulphur Dioxide and Ozone. An Ab Initio Study. Molecules 2021, 26, 626. https://doi.org/ $10.3390 /$ molecules 26030626

Academic Editor: Cecilia Coletti

Received: 1 January 2021

Accepted: 20 January 2021

Published: 25 January 2021

Publisher's Note: MDPI stays neutral with regard to jurisdictional claims in published maps and institutional affiliations.

Copyright: (C) 2021 by the author. Licensee MDPI, Basel, Switzerland. This article is an open access article distributed under the terms and conditions of the Creative Commons Attribution (CC BY) license (https:// creativecommons.org/licenses/by/ $4.0 /)$.
School of Chemistry and Physics, University of KwaZulu-Natal, Westville Campus, Private Bag X54001, Durban 4000, South Africa; ford@ukzn.ac.za

\begin{abstract}
The structures of a number of dimers of sulphur dioxide and ozone were optimized by means of a series of ab initio calculations. The dimer species were classified as either genuine energy minima or transition states of first or higher order, and the most probable structures consistent with the experimental data were confirmed. The molecular orbitals engaged in the interactions resulting in adduct formation were identified and relations between the orbitals of the dimers of the valence isoelectronic monomer species were examined. The vibrational spectra of the most probable structures were computed and compared with those reported in the literature, particularly with spectra observed in cryogenic matrices. The calculations were extended to predict the properties of a number of possible heterodimers formed between sulphur dioxide and ozone.
\end{abstract}

Keywords: ab initio; sulphur dioxide; ozone; dimers; complexes; structures; vibrational spectra

\section{Introduction}

Among the family of non-covalent interactions [1], the chalcogen bond has enjoyed much prominence in recent years. The definition of a chalcogen bond is a "net attractive interaction between an electrophilic region associated with a chalcogen atom in a molecular entity and a nucleophilic region in another, or the same, molecular entity" [2]. Interest in non-covalent bonding in species containing oxygen and sulphur atoms has prompted us to revisit our theoretical study of the sulphur dioxide dimer [3], with particular emphasis on its vibrational spectrum, and to extend our computations to the dimer of the valence isoelectronic analogue ozone. The weakly-bound sulphur dioxide homodimer has been the subject of a number of theoretical investigations [3-9]; in most of these studies the authors considered a number of potential candidates for the global minimum structure, using a variety of medium-sized basis sets. Gas phase studies have been carried out on the dimer by microwave and radiofrequency spectroscopy [9-12], while the infrared spectrum of sulphur dioxide has been extensively investigated in cryogenic matrices [13-23]. In many of these vibrational studies the $\mathrm{SO}_{2}$ dimer has been specifically identified. Sulphur dioxide also forms binary complexes with a variety of atoms and other small molecules; theoretical studies have included those with $\mathrm{H}_{2} \mathrm{~S}$ and $\mathrm{HCN}$ [5], $\mathrm{H}_{2} \mathrm{O}$ [5,11], $\mathrm{Ar}$ [6], $\mathrm{BF}_{3}$ [24], $\mathrm{C}_{2} \mathrm{H}_{2}$ [25], $\mathrm{CHCl}_{3}$ [26], $\mathrm{NH}_{3}$ and $\left(\mathrm{CH}_{3}\right)_{3} \mathrm{~N}$ [27], $\mathrm{CO}_{2}, \mathrm{OCS}, \mathrm{CS}_{2}$ and $\mathrm{N}_{2} \mathrm{O}$ [28], $\mathrm{NH}_{3}, \mathrm{H}_{2} \mathrm{O}, \mathrm{HF}, \mathrm{PH}_{3}$, $\mathrm{H}_{2} \mathrm{~S}$ and $\mathrm{HCl}$ [29], and $\mathrm{CH}_{3} \mathrm{CN}$ [30]. Many of these, and other, binary complexes have been observed in the gas phase, including those with $\mathrm{H}_{2} \mathrm{O}$ [11], $\mathrm{BF}_{3}$ [24], $\mathrm{CH}_{3} \mathrm{CN}$ [30], $\mathrm{HF}$ and $\mathrm{HCN}$ [31], $\mathrm{C}_{2} \mathrm{H}_{2}$ [32], $\mathrm{C}_{5} \mathrm{H}_{5} \mathrm{~N}$ [33], $\left(\mathrm{CH}_{3}\right)_{2} \mathrm{O}$ [34], $\mathrm{CO}_{2}$ [35], OCS [36], $\mathrm{CS}_{2}$ [37], $\mathrm{N}_{2} \mathrm{O}$ [38], and $\mathrm{CHCl}_{3}$ [39]. As was the case for the $\mathrm{SO}_{2}$ dimer, matrix isolation vibrational spectroscopy has also proved a fruitful source of data on binary complexes of sulphur dioxide. In this way, complexes of $\mathrm{SO}_{2}$ with $\mathrm{CH}_{3} \mathrm{CN}$ [30], $\mathrm{Cl}_{2}, \mathrm{HBr}, \mathrm{H}_{2} \mathrm{O}, \mathrm{NH}_{3}$ and $\mathrm{C}_{2} \mathrm{H}_{4}$ [40], $\mathrm{NH}_{3}$ and $\left(\mathrm{CH}_{3}\right)_{3} \mathrm{~N}$ [41], $\mathrm{HF}$ [42], $\mathrm{H}_{2} \mathrm{O}$ [43], $\mathrm{C}_{6} \mathrm{H}_{6}$ [44], and $\mathrm{BF}_{3}$ [45] in cryogenic matrices have been characterized. 
Far less work has been reported on the analogous ozone dimer, indeed, only one theoretical study has apparently been carried out on this species [46]. The vibrational spectrum of ozone in cryogenic matrices has been investigated [16,47-59]. However, most of these studies have been more concerned with isotopic analysis [47,48,54,55], the geometry of the monomer [50], with fluorescence [53], or photochemical [55-59] reactions in the matrices. Only in one case was the ozone dimer mentioned [59], and in another example the appearance of additional absorptions was attributed to the existence of multiple trapping sites [51]. A number of binary complexes containing ozone have been observed in low-temperature matrices, including olefins [60], $\mathrm{HBr}, \mathrm{H}_{2} \mathrm{O}, \mathrm{NH}_{3}, \mathrm{H}_{2} \mathrm{CO}$ and $\mathrm{C}_{2} \mathrm{H}_{4}$ [61], $\mathrm{PH}_{3}$ [62,63], $\mathrm{HF}[42,64], \mathrm{H}_{2} \mathrm{O}$ [65], $\mathrm{H}_{2} \mathrm{O}$ and $\mathrm{SO}_{2}$ [66], $\mathrm{CH}_{2} \mathrm{~F}_{2}$ [67], $\mathrm{CO}$ [68], and $\mathrm{O}$ atoms [69]. In addition to the formation of binary complexes, ozone has been found to be a fairly reactive species in cryogenic matrices, and reactions between $\mathrm{O}_{3}$ and a range of small molecules and atoms have been analysed. These include reactions with $\mathrm{CS}_{2}$ and OCS [70], $\mathrm{C}_{2} \mathrm{H}_{4}$ [71], $\mathrm{NO}$ [72-74], $\mathrm{NO}_{2}$ [75], $\mathrm{N}_{2} \mathrm{H}_{4}$ [76], $\mathrm{AsH}_{3}$ [77], $\mathrm{SbH}_{3}$ [78], $\mathrm{P}_{2}$ and $\mathrm{P}_{4}$ [79-81], $\mathrm{HCN}$ [82], $\mathrm{Cl}_{2}$ and $\mathrm{Br}_{2}$ [83], $\mathrm{Cl}[84,85]$, and $\mathrm{Ne}$ atoms [86].

The $\mathrm{SO}_{2}-\mathrm{O}_{3}$ heterodimer has so far eluded investigation, either theoretically or experimentally.

\section{Results and Discussion}

\subsection{Molecular Structures}

A number of trial structures were investigated for each adduct. We used as a template the publication of Hargittai [87], which examined a set of seven likely structural models for the metal dihalides, which we considered candidates as potential structures for the sulphur dioxide dimer. This trial set included three cyclic, two "linear", and two bifurcated models, most of which were also investigated by other workers [3-6,8,9]. Along with the seven Hargittai structures, we also included two species that involved a S ... S interaction, with no expectation that they would be strong candidates for the preferred $\mathrm{SO}_{2}$ dimer structure, but simply for completeness. Our nine possible dimer structures are illustrated in Figure 1 and their symmetries, energies, and Hessian indices are given in Table 1. Figure 2 shows their relative energies, separated according to their classification as genuine minima or transition states. We conclude, in agreement with the previous works [3-6,9] and with most of the experimental data $[9,10,12,13,15,19,20,22,23]$, that our dimer 5 is the global minimum and is a non-symmetric species of $C_{s}$ symmetry. The centrosymmetric dimer 2 is also a genuine minimum, being less than $1 \mathrm{~kJ} \mathrm{~mol}^{-1}$ higher in energy. Dimer 2, however, being centrosymmetric, would not be observable by microwave spectroscopy, therefore, there is no possibility of identifying this structure in the gas phase. Table 2 reports the computed geometrical parameters of each dimer and their deviations from the corresponding monomer values. The perturbations of the bond lengths and bond angles from their monomer values are small (less than $0.3 \mathrm{pm}$ and $0.6^{\circ}$, respectively), indicating a weak interaction in each case.

Table 1. Properties of some dimers of sulphur dioxide.

\begin{tabular}{ccccc}
\hline Dimer & Symmetry & E/H & $\begin{array}{c}\text { Hessian } \\
\text { Index }\end{array}$ & $\begin{array}{c}\text { Relative Energy/ } \\
\text { kJ } \mathbf{~ m o l}^{-\mathbf{1}}\end{array}$ \\
\hline $\mathbf{5}$ & $\mathrm{C}_{\mathrm{s}}$ & -1095.9350367841 & 0 & 0 \\
$\mathbf{2}$ & $\mathrm{C}_{\mathrm{i}}$ & -1095.9347964954 & 0 & 0.63 \\
$\mathbf{3}$ & $\mathrm{C}_{2}$ & -1095.9343327207 & 1 & 1.85 \\
$\mathbf{7}$ & $\mathrm{C}_{\mathrm{s}}$ & -1095.9341435632 & 1 & 2.35 \\
$\mathbf{1}$ & $\mathrm{C}_{2 \mathrm{~h}}$ & -1095.9339022981 & 2 & 2.98 \\
$\mathbf{4}$ & $\mathrm{C}_{2 \mathrm{v}}$ & -1095.9326603555 & 2 & 6.24 \\
$\mathbf{6}$ & $\mathrm{C}_{2 \mathrm{v}}$ & -1095.9322872309 & 2 & 7.22 \\
$\mathbf{9}$ & $\mathrm{D}_{2 \mathrm{r}}$ & -1095.9300035125 & 2 & 13.32 \\
$\mathbf{8}$ & $\mathrm{D}_{2 \mathrm{~h}}$ & -1095.9298616093 & 4 & 13.59 \\
\hline
\end{tabular}




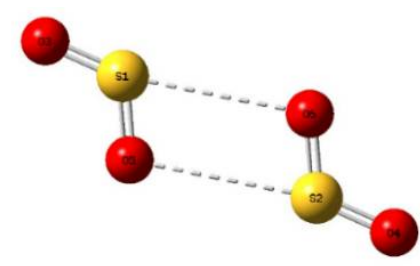

1

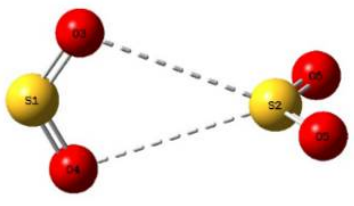

4

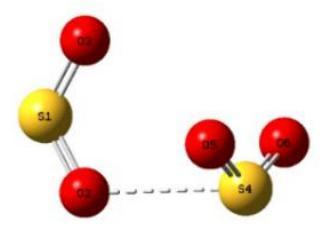

7

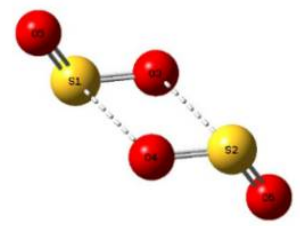

2

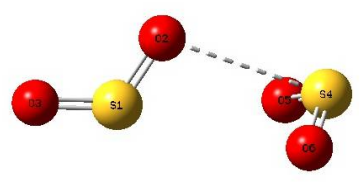

5

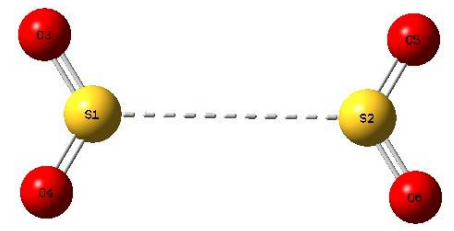

8

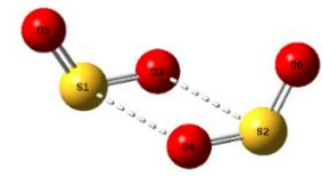

3

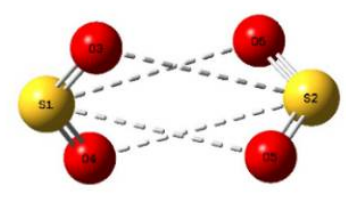

6

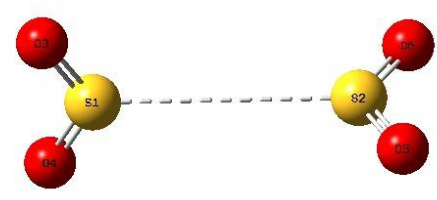

9

Figure 1. Optimized structures of some dimers of sulphur dioxide.

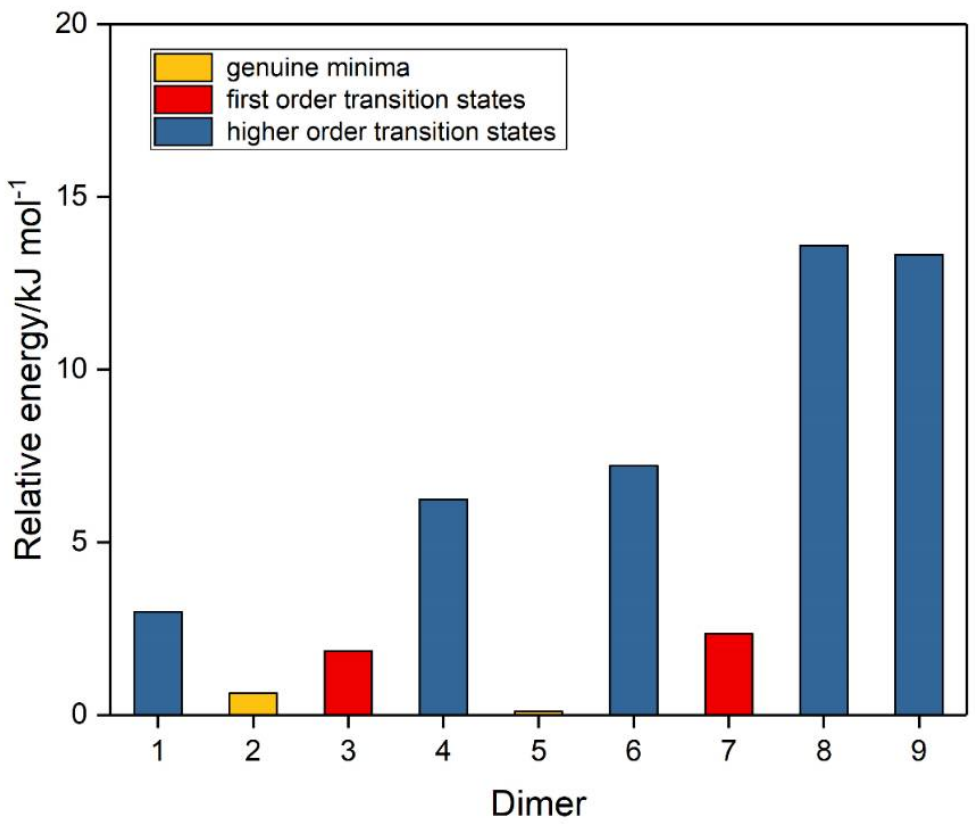

Figure 2. Relative energies of the sulphur dioxide dimers. 
Table 2. Optimized geometrical parameters of sulphur dioxide dimers $\mathbf{5}$ and $\mathbf{2}$, and their changes relative to the sulphur dioxide monomer. See Figure 1 for numbering of the atoms.

\begin{tabular}{|c|c|c|c|c|c|}
\hline \multicolumn{3}{|c|}{ Dimer 5} & \multicolumn{3}{|c|}{ Dimer 2} \\
\hline Parameter & Dimer Value & $\begin{array}{l}\text { Difference from } \\
\text { Monomer Value }\end{array}$ & Parameter & Dimer Value & $\begin{array}{l}\text { Difference from } \\
\text { Monomer Value }\end{array}$ \\
\hline $\mathrm{r}(\mathrm{S} 1 \mathrm{O} 2) / \mathrm{pm}$ & 146.57 & 0.21 & $\mathrm{r}(\mathrm{S} 1 \mathrm{O} 3, \mathrm{~S} 2 \mathrm{O} 4) / \mathrm{pm}$ & 146.51 & 0.15 \\
\hline $\mathrm{r}(\mathrm{S} 1 \mathrm{O} 3) / \mathrm{pm}$ & 146.32 & -0.03 & $\mathrm{r}(\mathrm{S} 1 \mathrm{O} 5, \mathrm{~S} 2 \mathrm{O} 6) / \mathrm{pm}$ & 146.30 & -0.05 \\
\hline $\mathrm{r}(\mathrm{S} 4 \mathrm{O} 5, \mathrm{~S} 4 \mathrm{O} 6) / \mathrm{pm}$ & 146.41 & 0.06 & $\angle \mathrm{O} 3 \mathrm{~S} 1 \mathrm{O} 5, \mathrm{O} 4 \mathrm{~S} 2 \mathrm{O} 6 / \mathrm{deg}$ & 118.40 & -0.39 \\
\hline$\angle \mathrm{O} 2 \mathrm{~S} 1 \mathrm{O} 3 / \mathrm{deg}$ & 118.21 & -0.58 & $\begin{array}{c}\mathrm{r}(\mathrm{S} 1 \ldots \mathrm{O} 4, \mathrm{~S} 2 \ldots \\
\mathrm{O} 3) / \mathrm{pm}\end{array}$ & 322.37 & - \\
\hline$\angle \mathrm{O} 5 \mathrm{~S} 4 \mathrm{O} 6 / \mathrm{deg}$ & 118.21 & -0.58 & $\begin{array}{c}\angle \mathrm{O} 5 \mathrm{~S} 1 \ldots \mathrm{O} 4, \mathrm{O} 6 \mathrm{~S} 2 \ldots \\
\text { O3/deg }\end{array}$ & 83.85 & - \\
\hline $\mathrm{r}(\mathrm{O} 2 \ldots \mathrm{S} 4) / \mathrm{pm}$ & 318.79 & - & $\begin{array}{c}\angle \mathrm{S} 1 \mathrm{O} 3 \ldots \mathrm{S} 2, \mathrm{~S} 2 \mathrm{O} 4 \ldots \\
\text { S1/deg }\end{array}$ & 106.60 & - \\
\hline$\angle \mathrm{S} 1 \mathrm{O} 2 \ldots \mathrm{S} 4 / \mathrm{deg}$ & 100.27 & - & $\angle \mathrm{O} 5 \mathrm{~S} 1 \mathrm{O} 3 \ldots \mathrm{S} 2 / \mathrm{deg}^{\mathrm{a}}$ & 73.23 & - \\
\hline $\begin{array}{c}\angle \mathrm{O} 2 \ldots \mathrm{S} 4 \mathrm{O} 5, \mathrm{O} 2 \ldots \\
\text { S4O6 } / \mathrm{deg}\end{array}$ & 79.37 & - & $\angle \mathrm{O} 6 \mathrm{~S} 2 \mathrm{O} 4 \ldots \mathrm{S} 1 / \mathrm{deg}^{\mathrm{a}}$ & -73.23 & - \\
\hline$\angle \mathrm{O} 5 \mathrm{~S} 4 \ldots \mathrm{O} 2 \mathrm{~S} 1 / \mathrm{deg}^{\mathrm{a}}$ & -60.82 & - & & & \\
\hline$\angle \mathrm{O} 6 \mathrm{~S} 4 \ldots \mathrm{O} 2 \mathrm{~S} 1 / \mathrm{deg}^{\mathrm{a}}$ & 60.82 & - & & & \\
\hline
\end{tabular}

The corresponding set of nine potential dimer structures for ozone are illustrated in Figure 3 and their properties are collected in Table 3. Their relative energies are presented in Figure 4. Only one of our ozone dimers (dimer 2 ) was found to be a true minimum. This adduct corresponds with the second lowest energy sulphur dioxide dimer, while the counterpart of the $\mathrm{C}_{\mathrm{s}}$ global minimum of $\left(\mathrm{SO}_{2}\right)_{2}$ (ozone dimer 5 ) is about $5 \mathrm{~kJ} \mathrm{~mol}^{-1}$ higher in energy. Our result is in contrast to that of Slanina and Adamowicz [46], who found the $\mathrm{C}_{\mathrm{S}}$ counterpart of our dimer 5 to be the global minimum species. Part of the difference may be attributed to the use of different basis sets, but it has long been realized that the ozone monomer presents particularly formidable challenges for computation [88,89], and this is even more apparent for its dimer. The parameters of our ozone dimer 2 species are shown in Table 4. Again, the perturbations are minimal (less than $0.25 \mathrm{pm}$ and $0.2^{\circ}$ ).

Table 3. Properties of some dimers of ozone.

\begin{tabular}{ccccc}
\hline Dimer & Symmetry & E/H & $\begin{array}{c}\text { Hessian } \\
\text { Index }\end{array}$ & $\begin{array}{c}\text { Relative Energy/ } \\
\text { kJ mol }^{-\mathbf{1}}\end{array}$ \\
\hline $\mathbf{2}$ & $\mathrm{C}_{\mathrm{i}}$ & -450.28419179490 & 0 & 0 \\
$\mathbf{3}$ & $\mathrm{C}_{2}$ & -450.28269146051 & 1 & 3.94 \\
$\mathbf{7}$ & $\mathrm{C}_{\mathrm{S}}$ & -450.28243399654 & 2 & 4.61 \\
$\mathbf{5}$ & $\mathrm{C}_{\mathrm{S}}$ & -450.28237307965 & 1 & 4.77 \\
$\mathbf{1}$ & $\mathrm{C}_{2 \mathrm{~h}}$ & -450.28054781872 & 2 & 9.57 \\
$\mathbf{4}$ & $\mathrm{C}_{2 \mathrm{v}}$ & -450.28020490636 & 4 & 10.47 \\
$\mathbf{9}$ & $\mathrm{D}_{2 \mathrm{~d}}$ & -450.27998305709 & 4 & 11.05 \\
$\mathbf{8}$ & $\mathrm{D}_{2 \mathrm{~h}}$ & -450.27991140084 & 5 & 11.24 \\
$\mathbf{6}$ & $\mathrm{C}_{2 \mathrm{v}}$ & -450.27936382300 & 2 & 12.68 \\
\hline
\end{tabular}

Based on the genuine minimum structures we found for the sulphur dioxide and ozone homodimers, and the $\mathrm{C}_{\mathrm{s}}$ first order transition state of $\left(\mathrm{O}_{3}\right)_{2}$, we examined eight structures for the sulphur dioxide-ozone heterodimer, two each corresponding with dimers $2,3,5$, and 7 , with sulphur dioxide and ozone acting as electron donor or electron acceptor in turn (a or b). These eight structures are illustrated in Figure 5 and their properties in Table 5. Structures $\mathbf{2} \mathbf{a}, \mathbf{2} \mathbf{b}, \mathbf{3 a}$, and $\mathbf{3} \mathbf{b}$ were found to be virtually identical; these four 
structures and complex $\mathbf{5 b}$ are all true minima. The relative energies are presented in Figure 6 and the bond lengths and angles and their changes in Table 6. Again, the pattern of very small perturbations is observed; only the free $\mathrm{O} 2 \mathrm{O} 6$ bond of the ozone sub-unit in complex $2 \mathbf{a}$ shows a substantial increase on complexation.

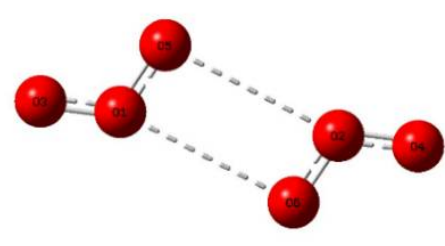

1

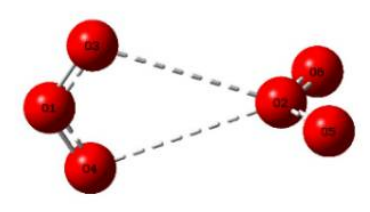

4

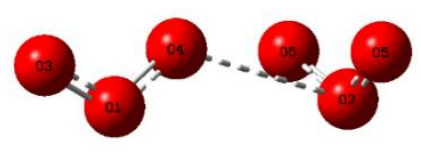

7

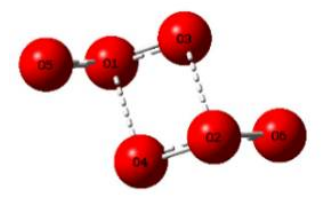

2

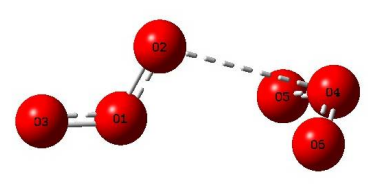

5

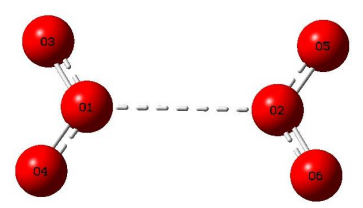

8

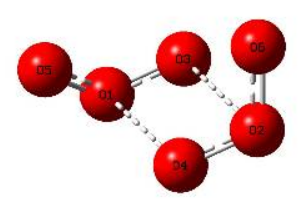

3

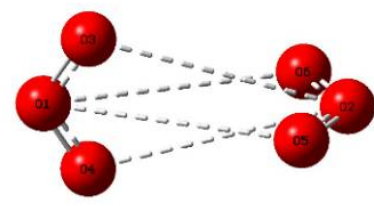

6

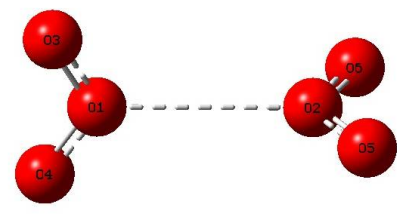

9

Figure 3. Optimized structures of some dimers of ozone.

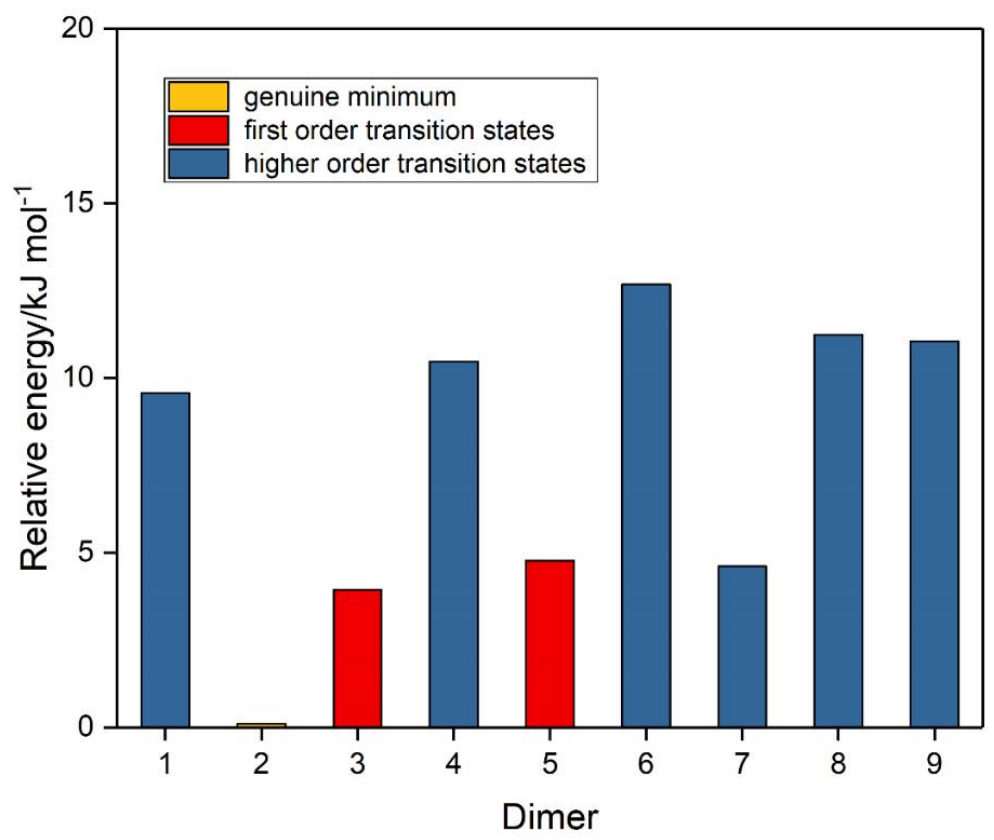

Figure 4. Relative energies of the ozone dimers. 
Table 4. Optimized geometrical parameters of ozone dimer $\mathbf{2}$ and their changes relative to the ozone monomer. See Figure 3 for numbering of the atoms.

\begin{tabular}{ccc}
\hline Parameter & Dimer Value & $\begin{array}{c}\text { Difference from } \\
\text { Monomer Value }\end{array}$ \\
\hline $\mathrm{r}(\mathrm{O} 1 \mathrm{O} 3, \mathrm{O} 2 \mathrm{O} 4) / \mathrm{pm}$ & 128.58 & 0.20 \\
$\mathrm{r}(\mathrm{O} 1 \mathrm{O} 5, \mathrm{O} 2 \mathrm{O} 6) / \mathrm{pm}$ & 128.53 & 0.15 \\
$\angle \mathrm{O} 3 \mathrm{O} 1 \mathrm{O} 5, \mathrm{O} 4 \mathrm{O} 2 \mathrm{O} 6 / \mathrm{deg}$ & 116.49 & -0.17 \\
$\mathrm{r}(\mathrm{O} 1 \ldots \mathrm{O} 4, \mathrm{O} 2 \ldots \mathrm{O} 3) / \mathrm{pm}$ & 299.07 & - \\
$\angle \mathrm{O} 5 \mathrm{O} 1 \ldots \mathrm{O} 4, \mathrm{O} 6 \ldots \mathrm{O} 2 \mathrm{O} 3 / \mathrm{deg}$ & 65.08 & - \\
$\angle \mathrm{O} 1 \mathrm{O} 3 \ldots \mathrm{O} 2, \mathrm{O} 2 \mathrm{O} 4 \ldots \mathrm{O} 1 / \mathrm{deg}$ & 108.32 & - \\
$\angle \mathrm{O} 5 \mathrm{O} 1 \ldots \mathrm{O} 4 \mathrm{O} 2 / \mathrm{deg}^{\mathrm{a}}$ & -43.17 & - \\
$\angle \mathrm{O} 6 \mathrm{O} 2 \ldots \mathrm{O} 3 \mathrm{O} 1 / \mathrm{deg}^{\mathrm{a}}$ & 43.17 & - \\
\hline
\end{tabular}

a Dihedral angle.

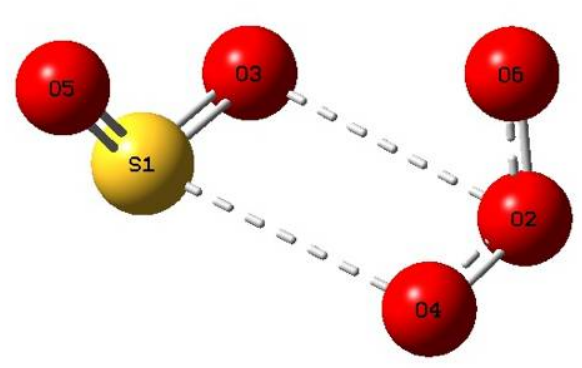

$2 \mathbf{a}$

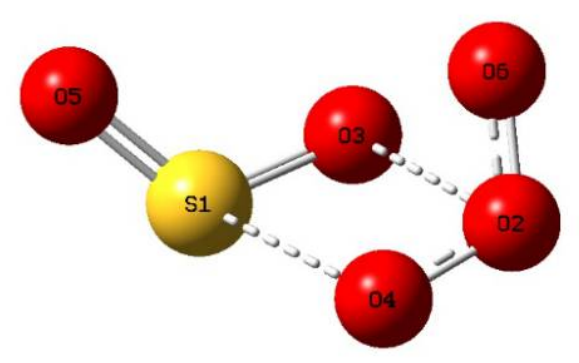

3a

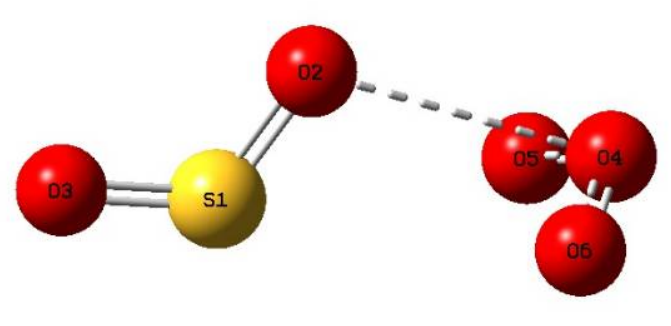

$5 a$

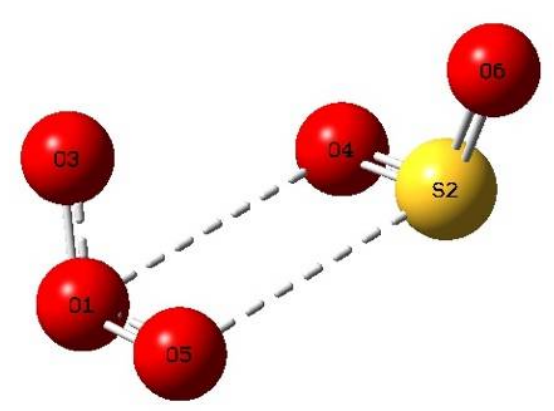

$2 \mathbf{b}$

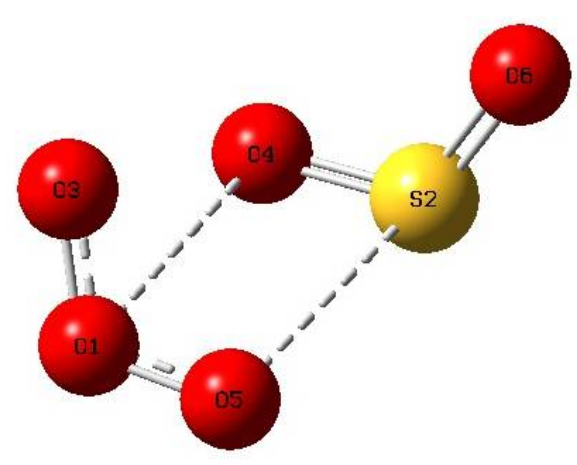

$3 b$

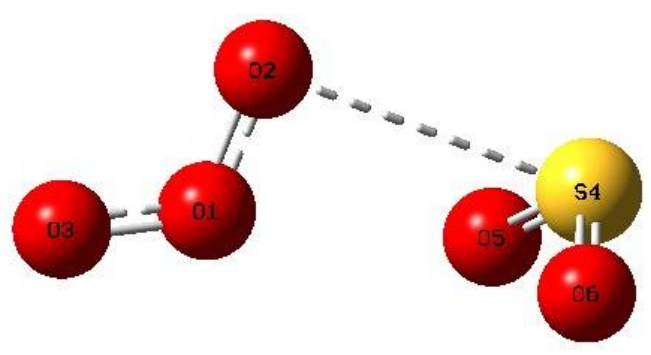

$5 b$

Figure 5. Cont. 


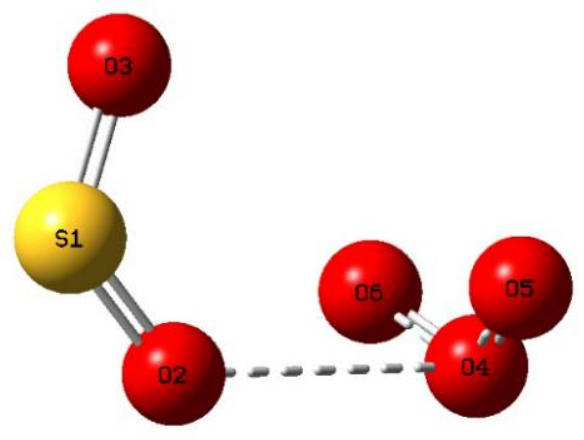

$7 a$

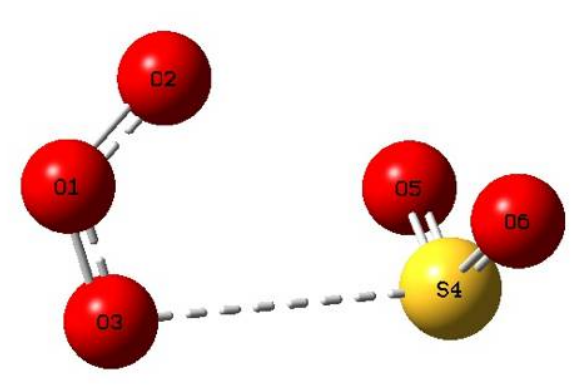

$7 \mathbf{b}$

Figure 5. Optimized structures of some complexes of sulphur dioxide and ozone.

Table 5. Properties of some complexes of sulphur dioxide and ozone.

\begin{tabular}{|c|c|c|c|c|}
\hline Complex & Symmetry & $\mathrm{E} / \mathrm{H}$ & $\begin{array}{c}\text { Hessian } \\
\text { Index }\end{array}$ & $\begin{array}{l}\text { Relative Energy/ } \\
\text { kJ mol }{ }^{-1}\end{array}$ \\
\hline $2 \mathbf{a}$ & $\mathrm{C}_{1}$ & -773.10980096467 & 0 & 0 \\
\hline $3 a$ & $\mathrm{C}_{1}$ & -773.10980095885 & 0 & 0 \\
\hline $2 \mathrm{~b}$ & $\mathrm{C}_{1}$ & -773.10980095755 & 0 & 0 \\
\hline $3 b$ & $C_{1}$ & -773.10980095165 & 0 & 0 \\
\hline $5 \mathbf{a}$ & $\mathrm{C}_{\mathrm{s}}$ & -773.10921061632 & 1 & 1.55 \\
\hline $7 \mathrm{~b}$ & $\mathrm{C}_{\mathrm{s}}$ & -773.10817161056 & 1 & 4.28 \\
\hline $7 a$ & $\mathrm{C}_{\mathrm{s}}$ & -773.10813721831 & 1 & 4.37 \\
\hline $5 b$ & $\mathrm{C}_{\mathrm{s}}$ & -773.10807683409 & 0 & 4.53 \\
\hline
\end{tabular}

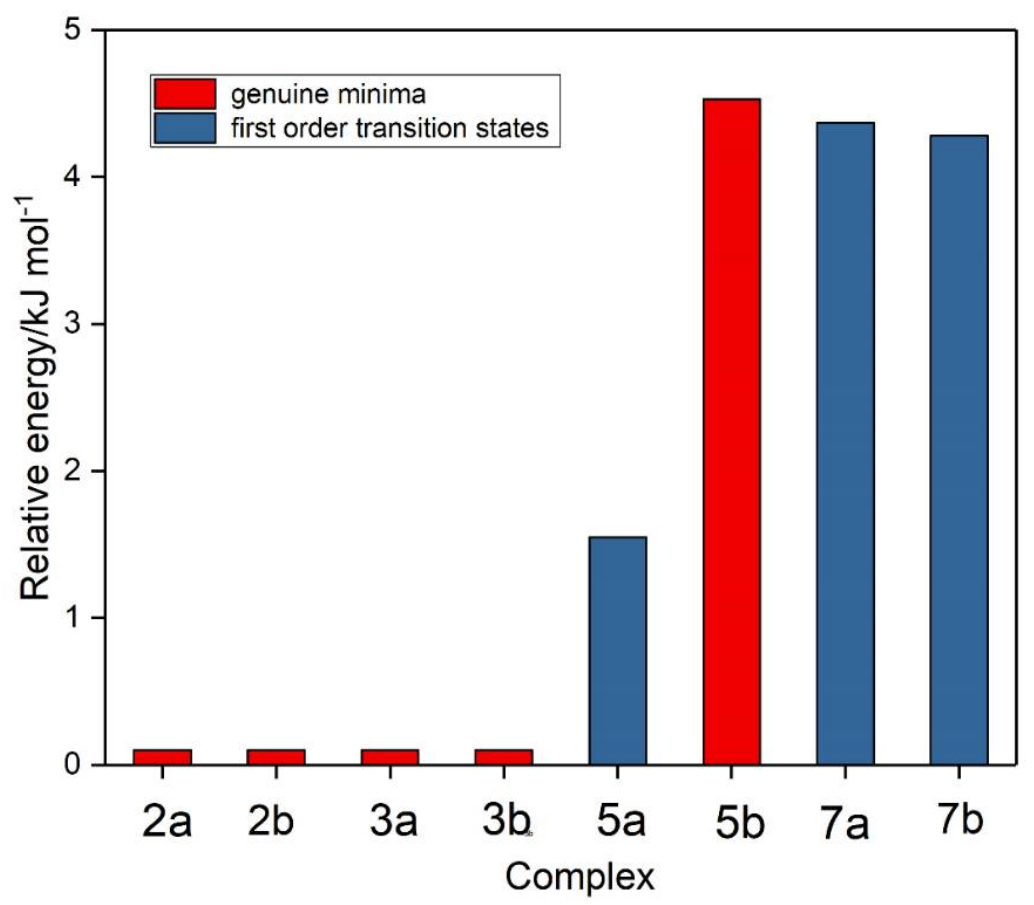

Figure 6. Relative energies of the sulphur dioxide-ozone complexes.

\subsection{Interaction Energies}

The interaction energies of the five genuine minimum energy structures are given in Table 7, corrected in each case for BSSE [90] and for zero-point energy differences. Consistent with the relatively insignificant intramolecular structural perturbations discussed 
above, the interaction energies are all less than $10 \mathrm{~kJ} \mathrm{~mol}^{-1}$; the two $\mathrm{SO}_{2}$ dimers and the 2a heterodimer all have similar energies, while heterodimer $\mathbf{5 b}$ is barely bound at all.

Table 6. Optimized geometrical parameters of sulphur dioxide-ozone complexes $\mathbf{2 a}$ and $\mathbf{5 b}$, and their changes relative to the sulphur dioxide and ozone monomers. See Figure 5 for numbering of the atoms.

\begin{tabular}{|c|c|c|c|c|c|}
\hline \multicolumn{3}{|c|}{ Complex 2a } & \multicolumn{3}{|c|}{ Complex 5b } \\
\hline Parameter & Dimer Value & $\begin{array}{l}\text { Difference from } \\
\text { Monomer Value }\end{array}$ & Parameter & Dimer Value & $\begin{array}{l}\text { Difference from } \\
\text { Monomer Value }\end{array}$ \\
\hline $\mathrm{r}(\mathrm{S} 1 \mathrm{O} 3) / \mathrm{pm}$ & 146.72 & 0.36 & $\mathrm{r}(\mathrm{O} 1 \mathrm{O} 2) / \mathrm{pm}$ & 128.03 & -0.35 \\
\hline $\mathrm{r}(\mathrm{S} 1 \mathrm{O} 5) / \mathrm{pm}$ & 146.21 & -0.15 & $\mathrm{r}(\mathrm{O} 1 \mathrm{O} 3) / \mathrm{pm}$ & 128.69 & 0.31 \\
\hline $\mathrm{r}(\mathrm{O} 2 \mathrm{O} 4) / \mathrm{pm}$ & 127.85 & -0.53 & $\mathrm{r}(\mathrm{S} 4 \mathrm{O} 5, \mathrm{~S} 4 \mathrm{O} 6) / \mathrm{pm}$ & 146.37 & 0.02 \\
\hline $\mathrm{r}(\mathrm{O} 2 \mathrm{O} 6) / \mathrm{pm}$ & 129.76 & 1.39 & $\angle \mathrm{O} 2 \mathrm{O} 1 \mathrm{O} 3 / \mathrm{deg}$ & 116.50 & -0.16 \\
\hline$\angle \mathrm{O} 3 \mathrm{~S} 1 \mathrm{O} 5 / \mathrm{deg}$ & 118.50 & -0.29 & $\angle \mathrm{O} 5 \mathrm{~S} 4 \mathrm{O} 6 / \mathrm{deg}$ & 118.51 & -0.28 \\
\hline$\angle \mathrm{O} 4 \mathrm{O} 2 \mathrm{O} 6 / \mathrm{deg}$ & 116.08 & -0.58 & $\mathrm{r}(\mathrm{O} 2 \ldots \mathrm{S} 4) / \mathrm{pm}$ & 313.42 & - \\
\hline $\mathrm{r}(\mathrm{S} 1 \ldots \mathrm{O} 4) / \mathrm{pm}$ & 291.71 & - & $\angle \mathrm{O} 1 \mathrm{O} 2 \ldots \mathrm{S} 4 / \mathrm{deg}$ & 90.03 & - \\
\hline $\mathrm{r}(\mathrm{O} 2 \ldots \mathrm{O} 3) / \mathrm{pm}$ & 291.42 & - & $\begin{array}{c}\angle \mathrm{O} 2 \ldots \mathrm{S} 4 \mathrm{O} 5, \mathrm{O} 2 . \\
\mathrm{S} 4 \mathrm{O} 6 / \mathrm{deg}\end{array}$ & 83.45 & - \\
\hline$\angle \mathrm{O} 5 \mathrm{~S} 1 \ldots \mathrm{O} 4 / \mathrm{deg}$ & 113.06 & - & $\angle \mathrm{O} 5 \mathrm{~S} 4 \ldots \mathrm{O} 2 \mathrm{O} 1 / \mathrm{deg}^{\mathrm{a}}$ & 59.89 & - \\
\hline$\angle \mathrm{O} 6 \mathrm{O} 2 \ldots \mathrm{O} 3 / \mathrm{deg}$ & 66.12 & - & $\angle \mathrm{O} 6 \mathrm{~S} 4 \ldots \mathrm{O} 2 \mathrm{O} 1 / \mathrm{deg}^{\mathrm{a}}$ & -59.89 & - \\
\hline$\angle \mathrm{O} 5 \mathrm{~S} 1 \mathrm{O} 3 \ldots \mathrm{O} 2 / \mathrm{deg}^{\mathrm{a}}$ & 107.94 & - & & & \\
\hline$\angle \mathrm{O} 6 \mathrm{O} 2 \mathrm{O} 4 \ldots \mathrm{S} 1 / \mathrm{deg}^{\mathrm{a}}$ & 55.56 & - & & & \\
\hline
\end{tabular}

Table 7. Interaction energies of some dimers and complexes of sulphur dioxide and ozone.

\begin{tabular}{|c|c|c|c|c|c|}
\hline \multirow{2}{*}{ Species } & \multicolumn{5}{|c|}{ Interaction Energy/kJ mol ${ }^{-1}$} \\
\hline & Raw & BSSE & Corrected & $\Delta \mathrm{E}_{\mathrm{o}}$ & Net \\
\hline $\mathrm{SO}_{2}$ dimer 5 & 13.26 & 2.38 & 10.88 & 1.93 & 8.95 \\
\hline $\mathrm{SO}_{2}$ dimer 2 & 12.59 & 2.26 & 10.33 & 1.86 & 8.47 \\
\hline $\mathrm{O}_{3}$ dimer 2 & 14.39 & 3.18 & 11.21 & 4.21 & 7.00 \\
\hline $\mathrm{SO}_{2}-\mathrm{O}_{3}$ complex $2 \mathrm{a}$ & 15.52 & 3.34 & 12.18 & 3.67 & 8.51 \\
\hline $\mathrm{SO}_{2}-\mathrm{O}_{3}$ complex $5 \mathbf{b}$ & 9.87 & 2.17 & 7.70 & 1.91 & 5.79 \\
\hline
\end{tabular}

\subsection{Molecular Orbital Properties}

The valence molecular orbitals of the sulphur dioxide and ozone monomers are illustrated in Figures 7 and 8, and their descriptions are listed in Tables 8 and 9. The energy ordering of the orbitals follows the conventional sequence, $\sigma<\operatorname{lp}(\mathrm{O}) \approx \operatorname{lp}(\mathrm{S})<\pi<\pi^{*}<\sigma^{*}$. One sulphur and four oxygen lone pairs are expected for the $\mathrm{SO}_{2}$ monomer, and four terminal and one central oxygen lone pair in the case of $\mathrm{O}_{3}$. For both $\mathrm{SO}_{2}$ and $\mathrm{O}_{3}$ the $\pi$ orbitals separate into a bonding orbital delocalized over all three atoms, a non-bonding orbital involving only the out-of-plane p orbitals of the peripheral oxygen atoms, and an antibonding orbital with contributions from the p orbitals of all three atoms. The $\sigma^{*}$ orbitals, being more diffuse and involving more excited atomic orbitals, are less easy to visualize and to assign. 


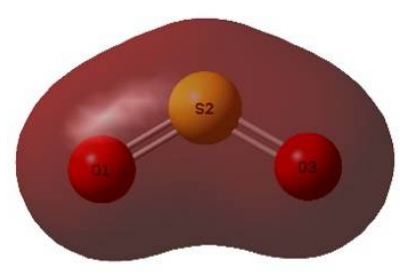

8 (a1)

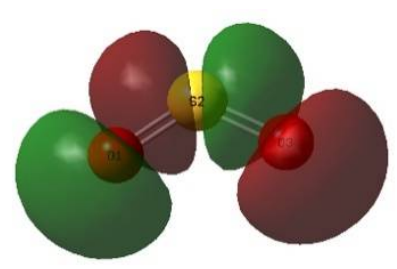

$11\left(b_{2}\right)$

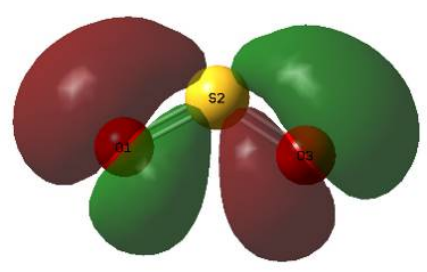

$14\left(\mathrm{~b}_{2}\right)$

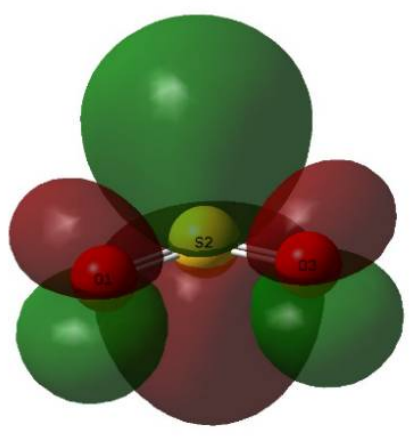

$17\left(b_{1}\right)$

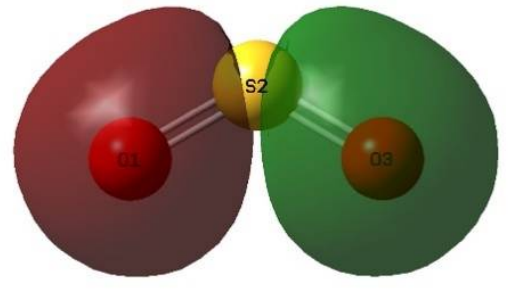

$9\left(b_{2}\right)$

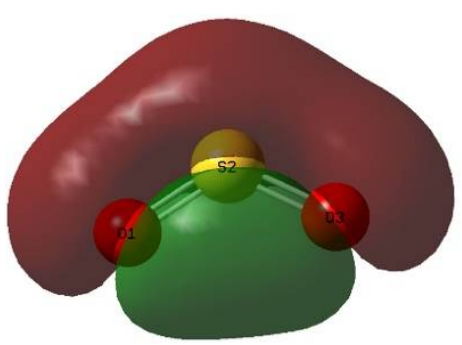

12 (a1)

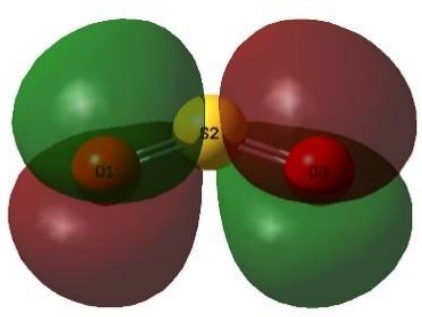

$15(\mathbf{a} 2)$

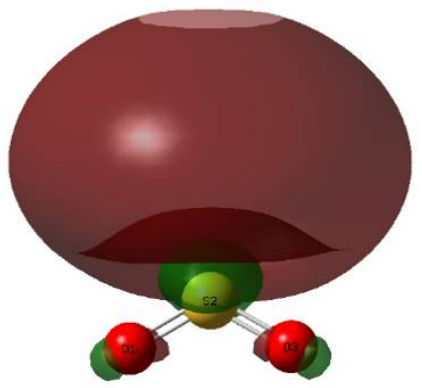

$18($ a1)

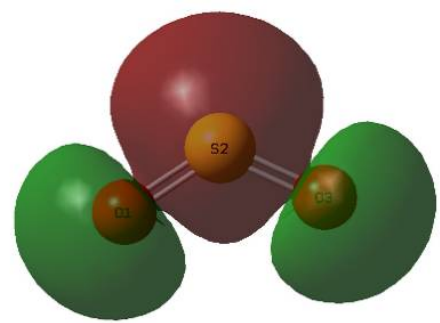

$10($ a1)

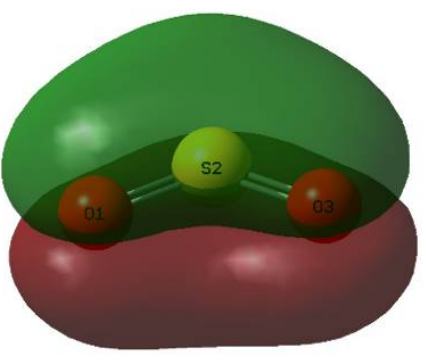

$13\left(b_{1}\right)$

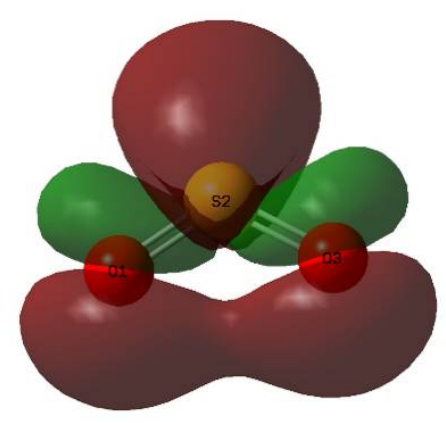

$16(\mathbf{a} 1)$

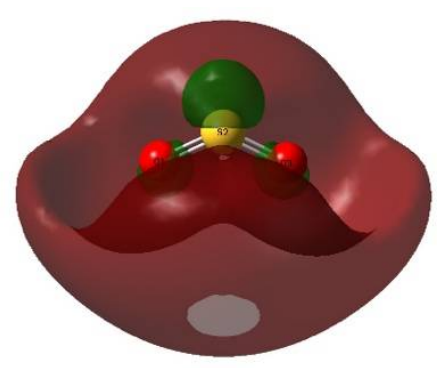

19 (a1)

Figure 7. Valence molecular orbitals of the sulphur dioxide monomer. 


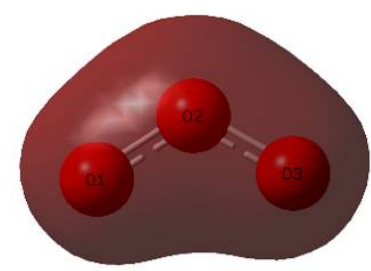

$4(\mathrm{a} 1)$

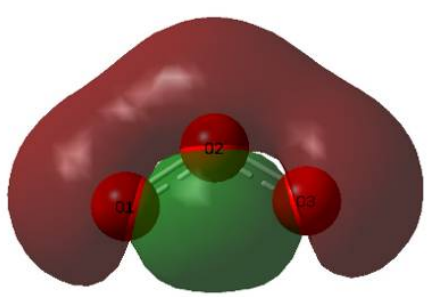

7 (a1)

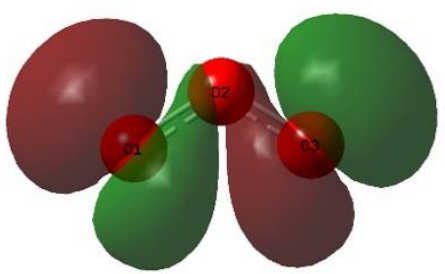

$10\left(b_{2}\right)$

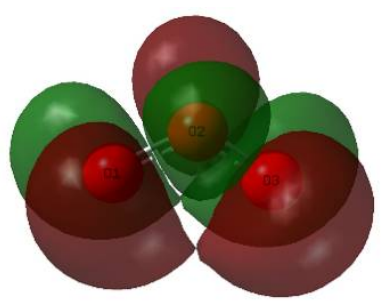

$13\left(b_{1}\right)$

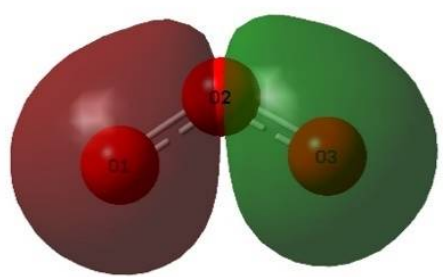

$5\left(\mathbf{b}_{2}\right)$

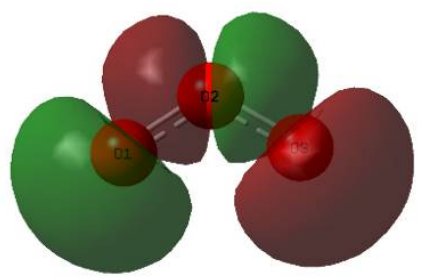

$8\left(b_{2}\right)$

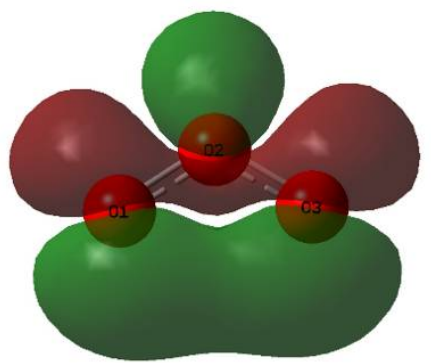

11 (a1)

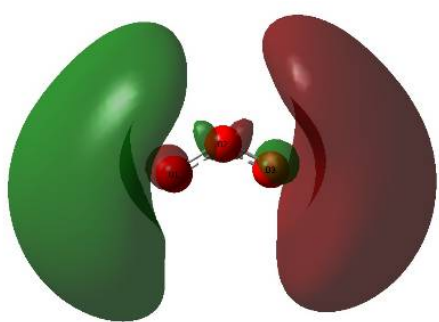

$14\left(b_{2}\right)$

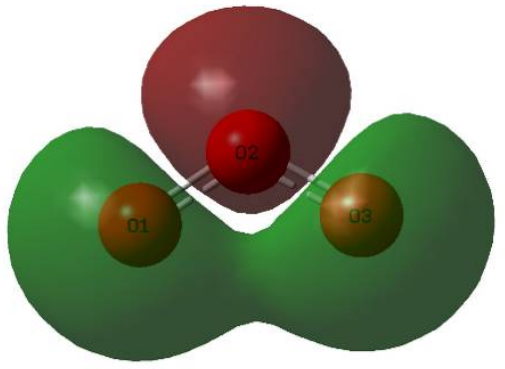

$6(\mathrm{a} 1)$

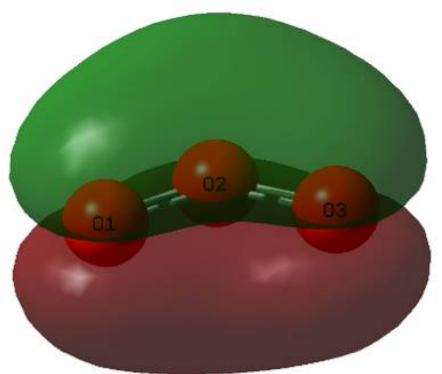

$9\left(b_{1}\right)$

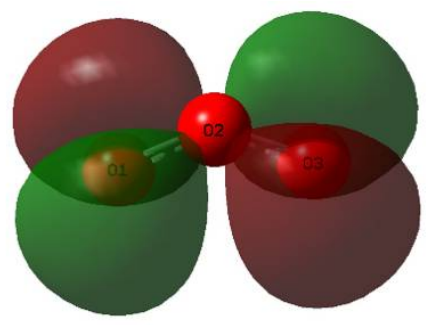

$12\left(a_{2}\right)$

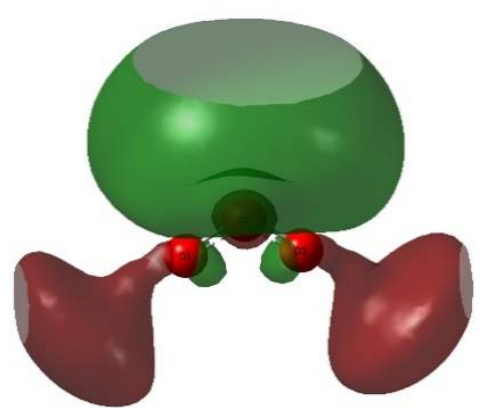

15 (a1)

Figure 8. Valence molecular orbitals of the ozone monomer.

These monomer orbitals transform readily into those of the dimer and complex species, and the orbitals of the five genuine minima are shown in the Supplementary Material as Figures S1-S5. The corresponding descriptions of the orbitals of the adducts are given in Supplementary Material Tables S1-S5. The major changes in the characters of the orbitals on complexation are that some of the lone pair orbitals of the monomers transform into $\sigma$ 
bonding orbitals associated with the intermolecular bonding interactions. Thus, for $\mathrm{SO}_{2}$ dimers $\mathbf{5}$ and $\mathbf{2}$, for example, four oxygen and one sulphur monomer lone pair orbitals go over into six oxygen and two sulphur lone pair orbitals, with two new $\sigma(\mathrm{S} \ldots \mathrm{O})$ orbitals.

Table 8. Properties of the valence molecular orbitals of the sulphur dioxide monomer.

\begin{tabular}{|c|c|c|c|}
\hline No. & Symmetry & Energy/H & Approximate Description ${ }^{a}$ \\
\hline $1-7$ & & & core \\
\hline 8 & $a_{1}$ & -1.48513 & $\sigma(\mathrm{OSO})$ \\
\hline 9 & $b_{2}$ & -1.38753 & $\sigma(\mathrm{OSO})$ \\
\hline 10 & $\mathrm{a}_{1}$ & -0.88026 & $\operatorname{lp}(S)$ \\
\hline 11 & $b_{2}$ & -0.69488 & $\operatorname{lp}(\mathrm{O})$ \\
\hline 12 & $a_{1}$ & -0.68513 & $\operatorname{lp}(\mathrm{O})$ \\
\hline 13 & $b_{1}$ & -0.65353 & $\pi(\mathrm{OSO})$ \\
\hline 14 & $b_{2}$ & -0.54142 & $\operatorname{lp}(\mathrm{O})$ \\
\hline 15 & $a_{2}$ & -0.51405 & $\pi(\mathrm{nb})(\mathrm{OSO})$ \\
\hline $16(\mathrm{HOMO})$ & $\mathrm{a}_{1}$ & -0.49779 & $\operatorname{lp}(\mathrm{O})$ \\
\hline 17 (LUMO) & $b_{1}$ & -0.00680 & $\pi^{*}(\mathrm{OSO})$ \\
\hline 18 & $\mathrm{a}_{1}$ & 0.06607 & $\sigma^{*}(\mathrm{OSO})$ \\
\hline 19 & $a_{1}$ & 0.07129 & $\sigma^{*}(\mathrm{OSO})$ \\
\hline
\end{tabular}

Table 9. Properties of the valence molecular orbitals of the ozone monomer.

\begin{tabular}{cccc}
\hline No. & Symmetry & Energy/H & Approximate Description ${ }^{\text {a,b }}$ \\
\hline $\mathbf{1 - 3}$ & & -1.74257 & core \\
\hline $\mathbf{4}$ & $\mathrm{a}_{1}$ & -1.42739 & $\sigma(\mathrm{OOO})$ \\
\hline $\mathbf{5}$ & $\mathrm{b}_{2}$ & -1.09905 & $\sigma(\mathrm{OOO})$ \\
\hline $\mathbf{6}$ & $\mathrm{a}_{1}$ & -0.82911 & $\mathrm{lp}(\mathrm{O} 2)$ \\
\hline $\mathbf{7}$ & $\mathrm{a}_{1}$ & -0.79824 & $\mathrm{lp}(\mathrm{O} 1)+\mathrm{lp}(\mathrm{O} 3)$ \\
\hline $\mathbf{8}$ & $\mathrm{b}_{2}$ & -0.77653 & $\mathrm{lp}(\mathrm{O} 1)-\mathrm{lp}(\mathrm{O} 3)$ \\
\hline $\mathbf{9}$ & $\mathrm{b}_{1}$ & -0.56576 & $\pi(\mathrm{OOO})$ \\
\hline $\mathbf{1 0}$ & $\mathrm{b}_{2}$ & -0.55546 & $\mathrm{lp}(\mathrm{O} 1)-\mathrm{lp}(\mathrm{O} 3)+\mathrm{lp}(\mathrm{O} 3)$ \\
\hline $\mathbf{1 1}$ & $\mathrm{a}_{1}$ & -0.48829 & $\pi(\mathrm{nb})(\mathrm{O} 1-\mathrm{O} 3)$ \\
\hline $\mathbf{1 2}(\mathrm{HOMO})$ & $\mathrm{a}_{2}$ & -0.05229 & $\pi^{*}(\mathrm{OOO})$ \\
\hline $\mathbf{1 3}(\mathrm{LUMO})$ & $\mathrm{b}_{1}$ & 0.10144 & $\sigma^{*}(\mathrm{OOO})$ \\
\hline $\mathbf{1 4}$ & $\mathrm{b}_{2}$ & 0.10566 & $\sigma^{*}(\mathrm{OOO})$ \\
\hline $\mathbf{1 5}$ & $\mathrm{a}_{1}$ & -1056 &
\end{tabular}

a 1 and $\mathrm{O} 3-$ terminal atoms; $\mathrm{O} 2$-central atom. ${ }^{\mathrm{b}} \mathrm{lp}$-lone pair; nb-non-bonding.

Further insights into the electronic rearrangements accompanying dimer or complex formation are provided by a consideration of the molecular electrostatic potential maps of the adducts. These plots are shown in Figure 9 for the five associated species. The diagrams indicate the regions of high electron density, shown in red, shading to more electropositive zones, shown in blue, with the peripheral oxygen atoms having the greatest negative potentials and the more positive potentials associated with the sulphur atoms and the central oxygen atoms of the ozone moieties. The potentials cover a range from about -240 to $240 \mathrm{~kJ} \mathrm{~mol}^{-1}$. 


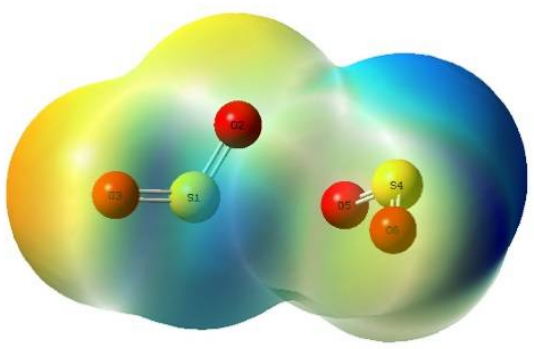

$\mathrm{SO}_{2}$ dimer 5

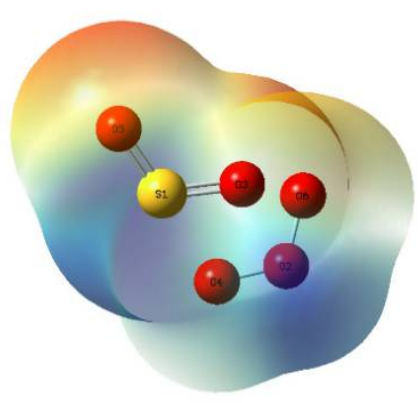

$\mathrm{SO}_{2}-\mathrm{O}_{3}$ complex $2 \mathrm{a}$

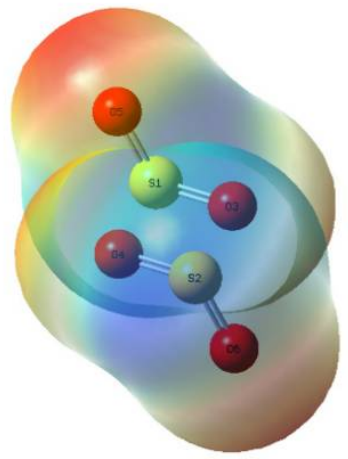

$\mathrm{SO}_{2}$ dimer 2

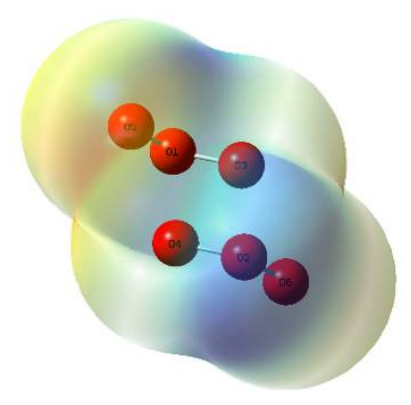

$\mathrm{O}_{3}$ dimer 2

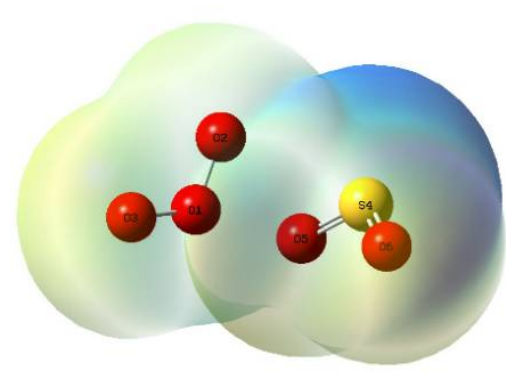

$\mathrm{SO}_{2}-\mathrm{O}_{3}$ complex $5 \mathbf{b}$

$-8.928 \mathrm{e}-2$

$8.928 \mathrm{e}-2$

Figure 9. Molecular electrostatic potential plots of some dimers and complexes of sulphur dioxide and ozone. Units: hartree $\left(1 \mathrm{H}=2625.346583 \mathrm{~kJ} \mathrm{~mol}^{-1}\right)$.

\subsection{Vibrational Spectra}

The computed wavenumbers of the five associated species, and their shifts relative to the uncomplexed monomers, are shown in Table 10. For the two sulphur dioxide dimers, the antisymmetric $\mathrm{SO}_{2}$ stretching modes tend to be displaced to the red and the symmetric stretching and the $\mathrm{SO}_{2}$ bending to the blue. These shifts are all less than $10 \mathrm{~cm}^{-1}$ in either direction, however, consistent with the very low interaction energies (see Table 7). The comparisons of our calculated intramolecular wavenumbers with experimental values derived from matrix isolation infrared spectroscopic studies [13,15,19-23] are given in Table 11. As a measure of the level of agreement between the calculated and experimental wavenumbers of $\mathrm{SO}_{2}$ dimer 5 , the calculated/experimental ratios derived from the data in Table 11 are found to vary between 1.029 for $v_{1}$ (relative to ref. [23]) to 1.060 for $v_{5}$ (ref. [22]).

The vibrational data are all in agreement that the observed spectra are compatible with the $\mathrm{C}_{\mathrm{s}}$ dimer $\mathbf{5}$ structure, except for the argon matrix results of Schriver-Mazzuoli et al. [21] and Ito and Hirabayashi [23], who proposed that the $C_{i}$ isomer $\mathbf{2}$ more closely fits the experimental data. Indeed, Schriver-Mazzuoli and co-workers were able to assign only one band in each of the fundamental monomer regions with confidence, consistent with only one mode in each of the monomer regions being infrared-active [21]. There are some minor mismatches among the assignments of the stretching modes [20,23], but definitive assignments to the bands of the electron donor and acceptor based on the experimental spectra alone are difficult to achieve. 
Table 10. Wavenumbers and wavenumber shifts of some dimers and complexes of sulphur dioxide and ozone.

\begin{tabular}{|c|c|c|c|c|c|c|c|c|}
\hline \multirow[b]{2}{*}{ Species } & \multicolumn{4}{|c|}{$\mathrm{SO}_{2}$} & \multicolumn{4}{|c|}{$\mathrm{O}_{3}$} \\
\hline & Symmetry & Mode $^{a}$ & $\begin{array}{l}\text { Wavenumber } \\
/ \mathrm{cm}^{-1}\end{array}$ & $\begin{array}{r}\text { Shift } \\
/ \mathrm{cm}^{-1}\end{array}$ & Symmetry & Mode & $\begin{array}{c}\text { Wavenumber } \\
/ \mathrm{cm}^{-1}\end{array}$ & $\begin{array}{l}\text { Shift } \\
/ \mathrm{cm}^{-1}\end{array}$ \\
\hline \multirow[t]{5}{*}{$\mathrm{SO}_{2}$ dimer 5} & $a^{\prime}$ & $v_{1}(\mathrm{ED})$ & 1300.5 & -5.0 & & & & \\
\hline & & $v_{2}(\mathrm{EA})$ & 1102.5 & 3.3 & & & & \\
\hline & & $v_{3}(\mathrm{ED})$ & 1099.1 & -0.1 & & & & \\
\hline & & $v_{4}(\mathrm{OP})$ & 500.0 & 6.7 & & & & \\
\hline & & $v_{5}(\mathrm{IP})$ & 494.6 & 1.3 & & & & \\
\hline \multirow[t]{6}{*}{$\mathrm{SO}_{2}$ dimer 2} & $a_{g}$ & $v_{1}(\mathrm{OP})$ & 1303.2 & -2.3 & & & & \\
\hline & & $v_{2}(\mathrm{IP})$ & 1101.4 & 2.2 & & & & \\
\hline & & $v_{3}(\mathrm{IP})$ & 494.9 & 1.6 & & & & \\
\hline & $a_{u}$ & $v_{7}(\mathrm{IP})$ & 1304.9 & -0.6 & & & & \\
\hline & & $v_{8}(\mathrm{OP})$ & 1101.5 & 2.3 & & & & \\
\hline & & $v_{9}(\mathrm{OP})$ & 495.8 & 2.5 & & & & \\
\hline \multirow[t]{4}{*}{$\mathrm{O}_{3}$ dimer 2} & & & & & $a_{g}$ & $v_{1}(\mathrm{OP})$ & 2419.3 & 175.0 \\
\hline & & & & & & $v_{2}(\mathrm{IP})$ & 1150.2 & -7.7 \\
\hline & & & & & & $v_{3}(\mathrm{IP})$ & 743.1 & 1.6 \\
\hline & & & & & & $v_{9}(\mathrm{OP})$ & 742.8 & 1.3 \\
\hline \multirow[t]{3}{*}{$\mathrm{SO}_{2}-\mathrm{O}_{3}$ complex $2 \mathrm{a}$} & a & $v_{2}$ & 1301.3 & -4.2 & a & $v_{1}$ & 2270.1 & 25.8 \\
\hline & & $v_{4}$ & 1096.5 & -2.7 & & $v_{3}$ & 1132.1 & -25.8 \\
\hline & & $v_{6}$ & 494.2 & 0.9 & & $v_{5}$ & 740.4 & -1.1 \\
\hline \multirow[t]{3}{*}{$\mathrm{SO}_{2}-\mathrm{O}_{3}$ complex $5 \mathbf{b}$} & $a^{\prime}$ & $v_{3}$ & 1102.4 & 3.2 & $a^{\prime}$ & $v_{1}$ & 2243.8 & -0.5 \\
\hline & & $v_{5}$ & 495.3 & 2.0 & & $v_{2}$ & 1159.2 & 1.3 \\
\hline & $a^{\prime \prime}$ & $v_{9}$ & 1306.2 & 0.7 & & $v_{4}$ & 744.7 & 3.2 \\
\hline
\end{tabular}


Table 11. Calculated and experimental intramolecular wavenumbers of sulphur dioxide dimer 5.

\begin{tabular}{|c|c|c|c|c|c|c|}
\hline \multirow{2}{*}{ Reference } & \multicolumn{6}{|c|}{ Wavenumber/cm ${ }^{-1}$ a } \\
\hline & $\begin{array}{c}v_{1}\left(a^{\prime}\right) \\
v_{a}\left(S_{2}\right)(E D)\end{array}$ & $\begin{array}{c}v_{2}\left(a^{\prime}\right) \\
v_{s}\left(S_{2}\right)(E A)\end{array}$ & $\begin{array}{c}v_{3}\left(\mathrm{a}^{\prime}\right) \\
v_{\mathrm{s}}\left(\mathrm{SO}_{2}\right)(\mathrm{ED})\end{array}$ & $\begin{array}{c}v_{4}\left(\mathbf{a}^{\prime}\right) \\
\delta\left(\mathrm{SO}_{2}\right)(\mathrm{OP})\end{array}$ & $\begin{array}{c}v_{5}\left(\mathbf{a}^{\prime}\right) \\
\delta\left(\mathrm{SO}_{2}\right)(\mathrm{IP})\end{array}$ & $\begin{array}{c}v_{9}\left(a^{\prime \prime}\right) \\
v_{a}\left(S_{2}\right)(E A)\end{array}$ \\
\hline This work ${ }^{b}$ & 1300.5 & 1102.5 & 1099.1 & 500.0 & 494.6 & 1303.9 \\
\hline Ref. [13] ${ }^{c}$ & $1343.1,1345.2$ & - & - & - & - & 1341.1 \\
\hline Ref. [15] ${ }^{d}$ & 1348.2 & 1155.8 & 1153.7 & 524.0 & 521.7 & 1345.6 \\
\hline Ref. [19] ${ }^{d}$ & 1349.2 & 1155.2 & 1153.9 & 526.1 & 524.0 & 1346.6 \\
\hline Ref. [20] ${ }^{d}$ & 1346.6 & 1151.8 & 1154.2 & 524.3 & 522.4 & 1349.1 \\
\hline Ref. [21] ${ }^{c}$ & 1341.3 & 1146.6 & - & 519.5 & - & - \\
\hline Ref. [22] ${ }^{c}$ & 1345.1 & 1155.4 & 1153.3 & 527.2 & 521.8 & 1341.1 \\
\hline Ref. [22] ${ }^{d}$ & 1349.4 & 1156.1 & 1154.3 & 526.5 & 524.3 & 1346.5 \\
\hline Ref. [23] ${ }^{c}$ & $1345.8,1346.5$ & $1154.8,1155.5$ & $1152.1,1152.8$ & - & - & $1348.2,1348.9$ \\
\hline Ref. [23] ${ }^{\mathrm{e}}$ & $1344.4,1345.2$ & $1152.9,1153.6$ & $1149.9,1150.5$ & - & - & $1346.3,1347.0$ \\
\hline Ref. [23] ${ }^{\mathrm{f}}$ & $1338.8,1339.6$ & $1149.0,1149.8$ & $1145.7,1146.3$ & - & - & $1341.1,1342.0$ \\
\hline
\end{tabular}

Table 10 includes the calculated data for ozone dimer 2 . The shifts of the antisymmetric $\mathrm{O}_{3}$ stretching modes are spectacularly large, given the low interaction energy of this dimer, and are of opposite sign. This result must be viewed in the context of the computed wavenumbers of the ozone monomer, $1157.9,741.5$, and $2244.3 \mathrm{~cm}^{-1}$ for $v_{1}, v_{2}$, and $v_{3}$, respectively, which may be compared with the experimental values of 1134.9, 716.0, and $1089.2 \mathrm{~cm}^{-1}$, reported by Barbe et al. [91]. This assignment admits a most unusual ordering of the stretching vibrations, with $v_{1}>v_{3}$, which has been confirmed by Lee et al. [88,89]. Slanina and Adamowicz [46] report values of 1135, 726, and $2391 \mathrm{~cm}^{-1}$ for the monomer wavenumbers, in much closer agreement with our results. The antisymmetric stretching mode shifts indicate a significant separation of the two (in-phase and out-of-phase) vibrations of $247.3 \mathrm{~cm}^{-1}$, compared with separations of only $3.4 \mathrm{~cm}^{-1}$ and $1.7 \mathrm{~cm}^{-1}$ for $\mathrm{SO}_{2}$ dimers 5 and 2, respectively, and of $17 \mathrm{~cm}^{-1}$ calculated for the $\mathrm{C}_{\mathrm{s}}$ isomer of $\left(\mathrm{O}_{3}\right)_{2}$ by Slanina and Adamowicz [46]. The anomalous position of the antisymmetric stretching wavenumber confirms the notoriously difficult task of accurately reproducing the experimental wavenumber of the ozone monomer theoretically $[88,89,92,93]$. These authors pointed out the multiconfigurational nature of the ground state of the ozone monomer, confirmed by a series of high-level computations, including at the CASSCF, MRCI, CCSD, and CCSD(T) levels of theory. In order to examine whether our treatment of the spectra of ozone and its dimer at the MP2/aug-cc-pVTZ level was sufficiently reliable, we repeated those calculations for the monomer at the CASSCF level. We selected the monomer for this test, since the experimental geometry [94] and vibrational spectrum [91] are well-established and are available for comparison. The comparisons of our geometrical parameters and vibrational wavenumbers at the MP2 and CASSCF levels with their experimental counterparts and with the parallel computations of Lee and Scuseria [89] are given in Tables 12 and 13. While the computed bond length and angle are rather insensitive to the level of theory employed, and show fairly similar calculated and experimental differences (see Table 12), the estimation of the antisymmetric $\mathrm{OO}$ stretching mode exhibits a large scatter; only the theoretical treatment of Lee and Scuseria using CCSD/TZ+2Pf methodology [89] correctly reproduces the experimental ordering of the $v_{1}$ and $v_{3}$ vibrations (see Table 13). These uncertainties are responsible for the large, computed shifts associated with the monomer 
$v_{3}$ mode. Our shifts of the symmetric stretching and bending modes of the ozone dimer are much more in line with those of the $\mathrm{SO}_{2}$ dimers (less than $10 \mathrm{~cm}^{-1}$ ).

Table 12. Calculated and experimental bond length and bond angle of the ozone monomer.

\begin{tabular}{ccc}
\hline & $\mathbf{r ( O O ) / \mathbf { p m }}$ & $\angle$ OOO/deg \\
\hline Experimental (ref. [94]) & 127.2 & 116.8 \\
MP2 (this work) & 128.38 & 116.62 \\
Difference & 1.18 & -0.18 \\
CASSCF (this work) & 125.51 & 115.82 \\
Difference & -1.69 & -0.98 \\
CCSD/TZ+2Pf (ref. [89]) & 125.2 & 117.5 \\
Difference & -1.97 & 0.7 \\
\hline
\end{tabular}

Table 13. Calculated and experimental wavenumbers $\left(\mathrm{cm}^{-1}\right)$ of the ozone monomer.

\begin{tabular}{cccc}
\hline & $\boldsymbol{v}_{\mathbf{1}}\left(\mathbf{a}_{\mathbf{1}}\right)$ & $\boldsymbol{v}_{\mathbf{2}}\left(\mathbf{a}_{\mathbf{1}}\right)$ & $\boldsymbol{v}_{\mathbf{3}}\left(\mathbf{b}_{\mathbf{2}}\right)$ \\
\hline Experimental (ref. [91]) & 1135 & 716 & 1089 \\
MP2 (this work) & 1157.9 & 741.5 & 2244.3 \\
Ratio & 1.02 & 1.04 & 2.06 \\
CASSCF (this work) & 1092.3 & 770.2 & 1358.4 \\
Ratio & 0.96 & 1.08 & 1.25 \\
CCSD/TZ+2Pf (ref. [89]) & 1280 & 758 & 1261 \\
Ratio & 1.13 & 1.06 & 1.16 \\
\hline
\end{tabular}

The computed wavenumber shifts of the $\mathrm{SO}_{2}$ moieties of $\mathrm{SO}_{2}-\mathrm{O}_{3}$ complexes $2 \mathrm{a}$ and $5 \mathbf{b}$ are quite consistent with those of the $\mathrm{SO}_{2}$ dimers (less than $5 \mathrm{~cm}^{-1}$, see Table 10). Similarly, the $\mathrm{O}_{3}$ shifts of heterodimer $\mathbf{5} \mathbf{b}$ are insignificant, but those of the symmetric and antisymmetric $\mathrm{O}_{3}$ stretching modes of complex 2a are quite substantial and of opposite sign, yielding a separation of $51.6 \mathrm{~cm}^{-1}$. While this separation is not as dramatic as the corresponding result for the $\mathrm{C}_{\mathrm{i}}$ ozone dimer, it is quite apparent that the antisymmetric stretching vibrations of ozone molecules in these homo- and heterodimers are extremely sensitive to complexation.

\section{Computational Methodology}

The calculations were carried out using Gaussian-16 [95], at the second order level of the Møller-Plesset perturbation theory (MP2) [96] with Dunning's augmented correlationconsistent polarized valence triple-zeta basis sets (aug-cc-pVTZ) [97,98]. Structures were optimized using the verytight keyword, where practicable, and stationary points were identified as genuine minima or transition states by vibrational analysis. The wavenumbers and infrared intensities of the resulting species were determined at the harmonic level. Interaction energies were computed and corrected for basis set superposition error (BSSE) [90], using the Boys-Bernardi full counterpoise procedure [99] and the counterpoise $=2$ keyword and for zero-point energy differences. Molecular orbital properties and molecular electrostatic potentials were examined using the Gaussian input keywords pop = full, density $=$ current, and cube(full,orbitals) [95]. The model chemistry employed here is consistent with those represented in a number of similar calculations [4-8] in terms of its ability to yield credible results.

\section{Conclusions}

A series of nine structures each of the sulphur dioxide and ozone homodimers and of eight of their heterodimers were investigated. Of these structures, two sulphur dioxide and one ozone dimer and two sulphur dioxide-ozone complexes were found to be genuine minima on their potential surfaces. These five species were all found to be very weakly bound (less than $10 \mathrm{~kJ} \mathrm{~mol}^{-1}$ ). These low interaction energies resulted in very small 
perturbations of the bond lengths and bond angles of the monomers (less than 0.36 and $1.39 \mathrm{pm}$ for the $\mathrm{SO}$ and $\mathrm{OO}$ bond lengths and $0.29^{\circ}$ and $0.58^{\circ}$ for the $\mathrm{OSO}$ and $\mathrm{OOO}$ angles, respectively). The minimal perturbations of the intramolecular geometries are matched by the small, computed wavenumber shifts (less than $7 \mathrm{~cm}^{-1}$ for the $\mathrm{SO}_{2}$ dimers and the $\mathrm{SO}_{2}$ sub-units of the heterodimers, and less than $10 \mathrm{~cm}^{-1}$ for the symmetric stretching and bending of the $\mathrm{O}_{3}$ moieties of the ozone dimers and the heterodimers). The exceptions to this statement are ozone dimer 2, where the shifts of the antisymmetric $\mathrm{O}_{3}$ stretching mode are 175.0 and $-72.3 \mathrm{~cm}^{-1}$, and $\mathrm{SO}_{2}-\mathrm{O}_{3}$ complex $2 \mathrm{a}$, where the $\mathrm{O}_{3}$ stretching vibrations undergo shifts of $25.8 \mathrm{~cm}^{-1}$ to the blue (antisymmetric) and the red (symmetric). The ozone moiety appears to be much more sensitive than sulphur dioxide to perturbations of their vibrational spectra due to complexation, but the conclusions regarding the magnitudes of the shifts have to be tempered by recognition of the wellknown susceptibility of ozone to the level of theoretical treatment $[88,89,92,93]$. Miliordos and Xantheas presented evidence that, while the bonding in $\mathrm{SO}_{2}$ consists of two $\sigma$ and two $\pi$ bonds, that in $\mathrm{O}_{3}$ is better described as a mixture of a closed shell structure featuring two O-O bonds having bond orders of 1.5 (a delocalized 3-centre-4-electron bond) $(82 \%)$ and a diradical structure with two $\sigma$ bonds, a lone pair on the central oxygen atom, and a single electron in a p orbital on each of the terminal atoms (18\%) [92]. Takeshita et al. concurred with respect to the description of the $\mathrm{SO}_{2}$ bonding arrangement (recoupled pair bonds), and the fact that $\mathrm{O}_{3}$ "has significantly more diradical character than $\mathrm{SO}_{2}$ " [93]. These fundamental differences are certainly partly responsible for the marked variations in the ability of sulphur dioxide and ozone to form stable dimers, and hence in the differences in the computed vibrational spectra of the dimers. Neither Miliordos and Xantheas [92] nor Takeshita and co-workers [93] offered any insights into the spectra of the monomers, nor into the properties of the dimers.

We acknowledge the limitations of our methodology as they apply to the ozone species, but in the interests of consistency with our other results, we stand by the conclusions presented in this work.

Supplementary Materials: The following are available online, Figures S1-S5 and Tables S1-S5: titles as indicated in Table of Contents.

Funding: This research was funded by the National Research Foundation of South Africa, grant number 2053648, and by the University of KwaZulu-Natal Research Fund.

Data Availability Statement: The data presented in this study are available from the author and in the Supplementary Material.

Acknowledgments: This material is based upon work supported by the National Research Foundation of South Africa. Any opinion, findings, and conclusions or recommendations expressed in this material are those of the author and do not necessarily reflect the views of the National Research Foundation. The author acknowledges the Centre for High Performance Computing (South Africa) for the use of computing facilities, and Anton Lopis for invaluable technical assistance. The author is also grateful to a reviewer for bringing references 92 and 93 to his attention. He looks back with pleasure on a number of valuable detailed technical discussions and convivial social interactions with Austin Barnes in several countries over many years.

Conflicts of Interest: The author declares no conflict of interest.

Sample Availability: No physical samples of the compounds are available.

\section{References}

1. Hobza, P.; Müller-Dethlefs, K. Non-Covalent Interactions. Theory and Experiment; RSC Publishing: Cambridge, UK, 2010.

2. Aakeroy, C.B.; Bryce, D.L.; Desiraju, G.R.; Frontera, A.; Legon, A.C.; Nicotra, F.; Rissanen, K.; Terraneo, S.S.G.; Metrangolo, P.; Resnati, G. Definition of the chalcogen bond (IUPAC recommendations 2019). Pure Appl. Chem. 2019, 91, 1889-1892. [CrossRef]

3. Nxumalo, L.M.; Ford, T.A. Ab initio calculations of the structural, energetic and vibrational properties of some hydrogen-bonded and van der Waals dimers. Part 2. Sulphur dioxide. Spectrochim. Acta Part A 1995, 51, 1847-1860. [CrossRef]

4. Bone, R.G.A.; le Sueur, C.R.; Amos, R.D.; Stone, A.J. Stationary points on the potential energy surfaces of $\left(\mathrm{SO}_{2}\right)_{2}$ and $\left(\mathrm{SO}_{2}\right)_{3}$. J. Chem. Phys. 1992, 96, 8390-8410. [CrossRef] 
5. Plummer, P.L.M. Quantum mechanical studies of weakly-bound molecular clusters. J. Mol. Struct. (Theochem) 1994, 307, 119-133. [CrossRef]

6. Bone, R.G.A.; Bader, R.F.W. Identifying and analyzing intermolecular bonding interactions in van der Waals molecules. J. Phys. Chem. 1996, 100, 10892-10911. [CrossRef]

7. McKee, M.L. Computational study of the mono- and dianions of $\mathrm{SO}_{2}, \mathrm{SO}_{3}, \mathrm{SO}_{4}, \mathrm{~S}_{2} \mathrm{O}_{3}, \mathrm{~S}_{2} \mathrm{O}_{4}, \mathrm{~S}_{2} \mathrm{O}_{6}$ and $\mathrm{S}_{2} \mathrm{O}_{8}$. J. Phys. Chem. 1996, 100, 3473-3481. [CrossRef]

8. Groves, C.; Lewars, E. Dimers, trimers and oligomers of sulfur oxides: An ab initio and density functional study. J. Mol. Struct. (Theochem) 2000, 530, 265-279. [CrossRef]

9. Ito, F. Gas phase infrared spectra of $\mathrm{SO}_{2}$ clusters and quantum chemical calculations of some stable isomers. Chem. Phys. Letters 2007, 436, 335-340. [CrossRef]

10. Nelson, D.D.; Fraser, G.T.; Klemperer, W. The microwave and radiofrequency rotation-inversion spectrum of $\left(\mathrm{SO}_{2}\right)_{2}$. J. Chem. Phys. 1985, 83, 945-949. [CrossRef]

11. Matsumura, K.; Lovas, F.J.; Suenram, R.D. The microwave spectrum and structure of the $\mathrm{H}_{2} \mathrm{O}-\mathrm{SO}_{2}$ complex. J. Chem. Phys. 1989, 91, 5887-5894. [CrossRef]

12. Taleb-Bendiab, A.; Hillig, K.W., II; Kuczkowski, R.L. The microwave spectrum, structure and tunneling motion of the sulfur dioxide dimer. J. Chem. Phys. 1991, 94, 6956-6963. [CrossRef]

13. Hastie, J.W.; Hauge, R.; Margrave, J.L. Infrared spectra and geometry of $\mathrm{SO}_{2}$ and $\mathrm{SeO}_{2}$ in rare gas matrices. J. Inorg. Nucl. Chem. 1969, 31, 281-289. [CrossRef]

14. Allavena, M.; Rysnik, R.; White, D.; Calder, V.; Mann, D.E. Infrared spectra and geometry of $\mathrm{SO}_{2}$ isotopes in solid krypton matrices. J. Chem. Phys. 1969, 50, 3399-3409. [CrossRef]

15. Fredin, L. An exploratory study of weak molecular complexes in low temperature matrices. Chem. Scripta 1973, 4, 97-102.

16. Spoliti, M.; Grosso, V.; Nunziante-Cesaro, S. Infrared matrix isolation of, and bonding in, the oxides of group VIB elements: $\mathrm{O}_{3}$, $\mathrm{SO}_{2}, \mathrm{SeO}_{2}$ and $\mathrm{TeO}_{2}$. J. Mol. Struct. 1974, 21, 7-15. [CrossRef]

17. Maillard, D.; Allavena, M.; Perchard, J.P. Spectres vibrationnels du dioxide de soufre dans une matrice d'argon, d'azote et de neon. Spectrochim. Acta Part A 1975, 31, 1523-1531. [CrossRef]

18. Sodeau, J.R.; Lee, E.K.C. Photo-oxidation of sulfur dioxide in low temperature matrices. J. Phys. Chem. 1980, 84, 3358-3362. [CrossRef]

19. Nord, L. On the sulphur dioxide dimer in solid nitrogen. J. Mol. Struct. 1982, 96, 19-25. [CrossRef]

20. Wierzejewka-Hnat, M.; Schriver, A.; Schriver-Mazzuoli, L. FT infrared study of sulfur dioxide dimer. I. Nitrogen matrix. Chem. Phys. 1994, 183, 117-126. [CrossRef]

21. Schriver-Mazzuoli, L.; Schriver, A.; Wierzejewka-Hnat, M. Fourier transform infrared study of sulfur dioxide dimer. II. Argon matrix. Chem. Phys. 1995, 199, 227-243. [CrossRef]

22. Nxumalo, L.M.; Ford, T.A. The sulphur dioxide dimer. A matrix isolation infrared spectroscopic study. J. Mol. Struct. 1995, 347, 495-508. [CrossRef]

23. Ito, F.; Hirabayashi, S. Infrared spectroscopy of $\mathrm{SO}_{2}$ clusters in rare gas matrices revisited. Assignment of species in Ar matrices. Chem. Phys. 2009, 358, 209-218. [CrossRef]

24. Peebles, S.A.; Sun, L.; Kuczkowski, R.L.; Nxumalo, L.M.; Ford, T.A. The structure of the boron trifluoride-sulphur dioxide complex. J. Mol. Struct. 1998, 471, 235-242. [CrossRef]

25. Rayon, V.M.; Sordo, J.A. Acetylene-sulfur dioxide van der Waals complexes. A theoretical study. Chem. Phys. Lett. 2001, 341, 575-584. [CrossRef]

26. Hippler, M. Quantum chemical study of $\mathrm{CHCl}_{3}-\mathrm{SO}_{2}$ association. J. Chem. Phys. 2005, 123, 204311. [CrossRef]

27. Steudel, R.; Steudel, Y. Charge-transfer complexes between the sulfur molecules $\mathrm{SO}_{2}, \mathrm{~S}_{2} \mathrm{O}, \mathrm{S}_{3}, \mathrm{SONH}$ and $\mathrm{SOCl}_{2}$ and the amine donors $\mathrm{NH}_{3}$ and $\mathrm{NMe}_{3}-\mathrm{A}$ theoretical study. Eur. J. Inorg. Chem. 2007, 2007, 4385-4392. [CrossRef]

28. Venayagamoorthy, M.; Ford, T.A. Ab initio molecular orbital studies of the vibrational spectra of some van der Waals complexes. Part 4. Complexes of sulphur dioxide with carbon dioxide, carbonyl sulphide, carbon disulphide and nitrous oxide. S. Afr. J. Chem. 2009, 62, 149-155.

29. Ford, T.A. Ab initio molecular orbital calculations of the structures and vibrational spectra of some molecular complexes containing sulphur dioxide. J. Mol. Struct. 2009, 924-926, 466-472. [CrossRef]

30. Eigner, A.A.; Wrass, J.P.; Smith, E.L.; Knutson, C.C.; Phillips, J.A. Structural properties of $\mathrm{CH}_{3} \mathrm{CN}_{-} \mathrm{SO}_{2}$ in the gas phase and condensed-phase media via density functional theory and infrared spectroscopy. J. Mol. Struct. 2009, 919, 312-320. [CrossRef]

31. Dayton, D.C.; Miller, R.E. Infrared spectroscopy of the sulfur dioxide-hydrogen fluoride and hydrogen cyanide-sulfur dioxide binary complexes. J. Phys. Chem. 1990, 94, 6641-6646. [CrossRef]

32. Andrews, A.M.; Hillig, K.W., II; Kuczkowski, R.L.; Legon, A.C.; Howard, N.W. Microwave spectrum, structure, dipole moment and deuterium nuclear quadrupole coupling constants of the acetylene-sulfur dioxide van der Waals complex. J. Chem. Phys. 1991, 94, 6947-6955. [CrossRef]

33. Oh, J.J.; Hillig, K.W.; Kuczkowski, R.L. Microwave spectrum and structure of the pyridine-sulfur dioxide complex. J. Am. Chem. Soc. 1991, 113, 7480-7484. [CrossRef]

34. Oh, J.J.; Hillig, K.W.; Kuczkowski, R.L. Structure of the dimethyl ether-sulfur dioxide complex. Inorg. Chem. 1991, 30, 4583-4588. [CrossRef] 
35. Sun, L.; Ioannou, I.I.; Kuczkowski, R.L. The microwave spectrum and structure of the carbon dioxide-sulphur dioxide complex. Mol. Phys. 1996, 88, 255-268. [CrossRef]

36. Peebles, S.A.; Sun, L.H.; Ioannou, I.I.; Kuczkowski, R.L. Rotational spectrum, structure and modeling of the $\mathrm{SO}_{2}$-OCS complex. J. Mol. Struct. 1999, 485-486, 211-223. [CrossRef]

37. Peebles, S.A.; Sun, L.; Kuczkowski, R.L. Rotational spectrum, structure and modeling of the $\mathrm{SO}_{2}-\mathrm{CS}_{2}$ complex. J. Chem. Phys. 1999, 110, 6804-6811. [CrossRef]

38. Peebles, R.A.; Kuczkowski, R.L. Microwave spectrum of the $\mathrm{N}_{2} \mathrm{O}_{-} \mathrm{SO}_{2}$ dimer: Evidence for tunneling and an asymmetric structure. J. Phys. Chem. A 2000, 104, 4968-4975. [CrossRef]

39. Chung, S.; Hippler, M. Infrared spectroscopy of hydrogen-bonded $\mathrm{CHCl}_{3}-\mathrm{SO}_{2}$ in the gas phase. J. Chem. Phys. 2006, 124, 214316-214322. [CrossRef]

40. Nord, L. Some sulphur dioxide complexes in solid nitrogen. J. Mol. Struct. 1982, 96, 27-35. [CrossRef]

41. Sass, C.S.; Ault, B.S. Matrix isolation infrared spectroscopic study of sulfur dioxide-amine complexes. J. Phys. Chem. 1984, 88, 432-440. [CrossRef]

42. Andrews, L.; Withnall, R.; Hunt, R.D. Infrared spectra of the ozone ... hydrogen fluoride and sulfur dioxide ... hydrogen fluoride complexes in solid argon. J. Phys. Chem. 1988, 92, 78-81. [CrossRef]

43. Schriver, A.; Schriver, L.; Perchard, J.P. Infrared matrix isolation studies of complexes between water and sulfur dioxide: Identification and structures of the 1:1, 1:2 and 2:1 species. J. Mol. Spectrosc. 1988, 127, 125-142. [CrossRef]

44. Ault, B.S. Infrared spectroscopic characterization of $1: 1$ molecular complexes of $\mathrm{SO}_{2}$ with benzene and related conjugated $\pi$ electron donors in argon matrices. J. Mol. Struct. 1990, 238, 111-117. [CrossRef]

45. Nxumalo, L.M.; Ford, T.A. The Fourier transform infrared spectrum of the boron trifluoride-sulphur dioxide van der Waals complex. J. Mol. Struct. 2003, 661-662, 153-159. [CrossRef]

46. Slanina, Z.; Adamowicz, L. A computational study of the ozone dimer. J. Atmos. Chem. 1993, 16, 41-46. [CrossRef]

47. Andrews, L.; Spiker, R.C. Argon matrix Raman and infrared spectrum and vibrational analysis of ozone and the oxygen-18 substituted ozone molecules. J. Phys. Chem. 1972, 76, 3208-3213. [CrossRef]

48. Brewer, L.; Wang, J.L. Infrared absorption spectra of isotopic ozone isolated in rare-gas matrices. J. Chem. Phys. 1972, 56, 759-761. [CrossRef]

49. Hopkins, A.G.; Brown, D.W. Raman spectrum of matrix isolated ozone. J. Chem. Phys. 1973, 58, 1776-1777. [CrossRef]

50. Spoliti, M.; Nunziante-Cesaro, S.; Mariti, B. Infrared spectrum and geometry of ozone isolated in inert gas matrices at 20.4 K. J. Chem. Phys. 1973, 59, 985-986. [CrossRef]

51. Brosset, P.; Dahoo, R.; Gauthier-Roy, B.; Abouaf-Marguin, L. Analysis of IR absorption spectrum of $\mathrm{O}_{3}$ in inert matrices: Spectroscopic evidence for two trapping sites. Chem. Phys. 1993, 172, 315-324. [CrossRef]

52. Lakhlifi, A.; Girardet, C.; Dahoo, R.; Brosset, P.; Gauthier-Roy, B.; Abouaf-Marguin, L. Interpretation of the infrared spectrum of ozone trapped in inert matrices. Chem. Phys. 1993, 177, 31-44. [CrossRef]

53. Jasmin, D.; Brosset, P.; Dahoo, R.; Raducu, V.; Gauthier-Roy, B.; Abouaf-Marguin, L. Laser-induced infrared fluorescence of $\mathrm{O}_{3}$ trapped in xenon matrices. J. Chem. Phys. 1994, 101, 7337-7341. [CrossRef]

54. Schriver-Mazzuoli, L.; Schriver, A.; Lugez, C.; Perrin, A.; Camy-Peyret, C.; Flaud, J.M. Vibrational spectra of the ${ }^{16} \mathrm{O} /{ }^{17} \mathrm{O} /{ }^{18} \mathrm{O}$ substituted ozone molecule isolated in matrices. J. Mol. Spectrosc. 1996, 176, 85-94. [CrossRef]

55. Bahou, M.; Schriver-Mazzuoli, L.; Camy-Peyret, C.; Schriver, A. Photolysis of ozone at $693 \mathrm{~nm}$ in solid oxygen. Isotope effects in ozone reformation. Chem. Phys. Lett. 1997, 273, 31-36. [CrossRef]

56. Bahou, M.; Schriver-Mazzuoli, L.; Camy-Peyretm, C.; Schriver, A. New information on the ozone monomer photochemistry at $266 \mathrm{~nm}$ in nitrogen matrices. J. Chem. Phys. 1998, 108, 6884-6891. [CrossRef]

57. Flaud, J.M.; Bacis, R. The ozone molecule: Infrared and microwave spectroscopy. Spectrochim. Acta Part A 1998, 54, 3-16. [CrossRef]

58. Bahou, M.; Schriver-Mazzuoli, L.; Schriver, A. Photolysis at $266 \mathrm{~nm}$ of argon matrix isolated ozone monomer. J. Chem. Phys. 1999, 110, 8636-8642. [CrossRef]

59. Bahou, M.; Schriver-Mazzuoli, L.; Schriver, A. Infrared spectroscopy and photochemistry at 266 nm of the ozone dimer trapped in an argon matrix. J. Chem. Phys. 2001, 114, 4045-4052. [CrossRef]

60. Nelander, B.; Nord, L. Do ozone-olefin complexes really exist? J. Am. Chem. Soc. 1979, 101, 3769-3770. [CrossRef]

61. Nord, L. Ozone complexes in solid nitrogen. J. Mol. Struct. 1983, 96, 37-44. [CrossRef]

62. Withnall, R.; Hawkins, M.; Andrews, L. Infrared spectrum of a symmetrical phosphine-ozone complex in solid argon. J. Phys. Chem. 1986, 90, 575-579. [CrossRef]

63. Withnall, R.; Andrews, L. FTIR spectra of the photolysis products of the phosphine ozone complex in solid argon. J. Phys. Chem. 1987, 91, 784-797. [CrossRef]

64. Andrews, L. FTIR spectra of base-HF complexes in noble gas matrices. J. Mol. Struct. 1988, 173, 103-110. [CrossRef]

65. Schriver, L.; Barreau, C.; Schriver, A. Infrared spectroscopic and photochemical study of water-ozone complexes in solid argon. Chem. Phys. 1990, 140, 429-438. [CrossRef]

66. Schriver, L.; Carrere, D.; Schriver, A.; Jaeger, K. Matrix isolation photolysis of $\mathrm{SO}_{2}, \mathrm{O}_{3}$ and $\mathrm{H}_{2} \mathrm{O}$ : Evidence for the $\mathrm{H}_{2} \mathrm{O}: \mathrm{SO}_{3}$ complex. Chem. Phys. Lett. 1991, 181, 505-511. [CrossRef] 
67. Davis, S.R.; Liu, L. Matrix isolation IR spectroscopy, photochemistry and ab initio calculations of the difluoromethane-ozone complex. J. Phys. Chem. 1993, 97, 3690-3696. [CrossRef]

68. Raducu, V.; Jasmin, D.; Dahoo, R.; Brosset, P.; Gauthier-Roy, B.; Abouaf-Marguin, L. Experimental study of the CO:O 3 complex in argon matrices: Irradiation at $266 \mathrm{~nm}$. J. Chem. Phys. 1994, 101, 1878-1884. [CrossRef]

69. Schriver-Mazzuoli, L.; de Saxce, A.; Lugez, C.; Camy-Peyret, C.; Schriver, A. Ozone generation through photolysis of an oxygen matrix at $11 \mathrm{~K}$ : Fourier transform infrared spectroscopy identification of the $\mathrm{O} \ldots \mathrm{O}_{3}$ complex and isotopic studies. J. Chem. Phys. 1995, 102, 690-701. [CrossRef]

70. Jones, P.R.; Taube, H. Photochemical studies on ozone with carbon disulfide and with carbonyl sulfide in low-temperature matrixes. J. Phys. Chem. 1973, 77, 1007-1011. [CrossRef]

71. Nelander, B.; Nord, L. The reaction between ethylene and ozone. A matrix study. Tetrahedron Lett. 1977, 18, 2821-2822. [CrossRef]

72. Lucas, D.; Pimentel, G.C. Reaction between nitric oxide and ozone in solid nitrogen. J. Phys. Chem. 1979, 83, 2311-2316. [CrossRef]

73. Bhatia, S.C.; Hall, J.H., Jr. A matrix isolation infrared spectroscopic study of the reactions of nitric oxide with oxygen and ozone. J. Phys. Chem. 1980, 84, 3255-3259. [CrossRef]

74. Frei, H.; Pimentel, G.C. Reaction of nitric oxide and ozone in cryogenic matrices: Quantum-mechanical tunneling and vibrational enhancement. J. Phys. Chem. 1981, 85, 3355-3360. [CrossRef]

75. Morris, V.R.; Bhatia, S.C.; Hall, J.H. A study of the gas-phase reaction of nitrogen dioxide with ozone by matrix isolation infrared spectroscopy. J. Phys. Chem. 1987, 91, 3359-3361. [CrossRef]

76. Lascola, R.; Withnall, R.; Andrews, L. Infrared spectra of hydrazine and products of its reactions with $\mathrm{HF}, \mathrm{F}_{2}$ and $\mathrm{O}_{3}$ in solid argon. Inorg. Chem. 1988, 27, 642-648. [CrossRef]

77. Andrews, L.; Withnall, R.; Moores, B.W. Infrared spectra of arsine-ozone complexes, reaction products and photolysis products in solid argon. J. Phys. Chem. 1989, 93, 1279-1285. [CrossRef]

78. Andrews, L.; Moores, B.W.; Fonda, K.K. Matrix infrared spectra of reaction and photolysis products of stibine and ozone. Inorg. Chem. 1989, 28, 290-297. [CrossRef]

79. Andrews, L.; McCluskey, M.; Mielke, Z.; Withnall, R. Matrix reactions of $\mathrm{P}_{4}$ and $\mathrm{P}_{2}$ with $\mathrm{O}_{3}$ molecules. J. Mol. Struct. 1990, 222, 95-108. [CrossRef]

80. Mielke, Z.; McCluskey, M.; Andrews, L. Matrix reactions of $\mathrm{P}_{2}$ and $\mathrm{O}_{3}$ molecules. Chem. Phys. Lett. 1990, 165, 146-154. [CrossRef]

81. Mielke, Z.; Andrews, L. Matrix infrared spectra of the products from photochemical reactions of $\mathrm{P}_{4}$ with $\mathrm{O}_{3}$ and decomposition of $\mathrm{P}_{4} \mathrm{O}_{6}$. Inorg. Chem. 1990, 29, 2773-2779. [CrossRef]

82. Mielke, Z.; Andrews, L. Matrix infrared studies of the hydrogen cyanide + ozone and hydrogen cyanide + oxygen atom systems. J. Phys. Chem. 1990, 94, 3519-3525. [CrossRef]

83. Schriver-Mazzuoli, L.; Abdeloui, O.; Lugez, C.; Schriver, A. Matrix reaction of ozone with $\mathrm{Cl}_{2}$ and $\mathrm{Br}_{2}$. FTIR identification of $\mathrm{BrClO}$ and $\mathrm{ClBrO}$ species. Chem. Phys. Lett. 1993, 214, 519-526. [CrossRef]

84. Bhatia, S.C.; Hall, J.H., Jr. Matrix isolation infrared and laser Raman spectroscopic study of the gas-phase reactions of chlorine atoms and ozone. J. Phys. Chem. 1981, 85, 2055-2060. [CrossRef]

85. Carter, R.O., III; Andrews, L. Matrix spectroscopic studies of chlorine atom-ozone reaction products. J. Phys. Chem. 1981, 85, 2351-2354. [CrossRef]

86. Lugez, C.L.; Thompson, W.E.; Jacox, M.E. Matrix-isolated study of the interaction of excited neon atoms with $\mathrm{O}_{3}$ : Infrared spectrum of $\mathrm{O}_{3}{ }^{-}$and evidence for the stabilization of $\mathrm{O}_{2} \ldots \mathrm{O}_{4}{ }^{+}$. J. Chem. Phys. 1996, 105, 2153-2160. [CrossRef]

87. Hargittai, M. Molecular structure of metal halides. Chem. Rev. 2000, 100, 2233-2302. [CrossRef]

88. Lee, T.J.; Allen, W.D.; Schaefer, H.F., III. The analytical evaluation of energy first derivatives for two-configuration self-consistentfield configuration interaction (TCSCF-CI) wave functions. Application to ozone and ethylene. J. Chem. Phys. 1987, 87, 7062-7075. [CrossRef]

89. Lee, T.J.; Scuseria, G.E. The vibrational frequencies of ozone. J. Chem. Phys. 1990, 93, 489-494. [CrossRef]

90. Liu, B.; McLean, A.D. Accurate calculations of the attractive interactions of two ground state helium atoms. J. Chem. Phys. 1973, 59, 4557-4558. [CrossRef]

91. Barbe, A.; Secroun, C.; Jouve, P. Infrared spectra of ${ }^{16} \mathrm{O}_{3}$ and ${ }^{18} \mathrm{O}_{3}$; Darling and Dennison resonance and anharmonic potential function of ozone. J. Mol. Spectrosc. 1974, 49, 171-182. [CrossRef]

92. Miliordos, E.; Xantheas, S.S. On the bonding nature of ozone $\left(\mathrm{O}_{3}\right)$ and its sulphur-substituted analogues $\mathrm{SO}_{2}, \mathrm{OS}_{2}$ and $\mathrm{S}_{3}$ : Correlation between their diradical character and molecular properties. J. Am. Chem. Soc. 2014, 136, 2808-2817. [CrossRef]

93. Takeshita, T.Y.; Lindquist, B.A.; Dunning, T.H., Jr. Insights into the electronic structure of ozone and sulphur dioxide from generalized valence bond theory: Bonding in $\mathrm{O}_{3}$ and $\mathrm{SO}_{2}$. J. Phys. Chem. A 2015, 119, 7683-7694. [CrossRef]

94. Tanaka, T.; Morino, Y. Coriolis interaction and anharmonic potential function of ozone from the microwave spectra in the excited vibrational states. J. Mol. Spectrosc. 1970, 33, 538-551. [CrossRef]

95. Frisch, M.J.; Trucks, G.W.; Schlegel, H.B.; Scuseria, G.E.; Robb, M.A.; Cheeseman, J.R.; Scalmani, G.; Barone, V.; Petersson, G.A.; Nakatsuji, H.; et al. Gaussian 16, Revision A.03; Gaussian, Inc.: Wallingford, CT, USA, 2016.

96. Møller, C.; Plesset, M.S. Notes on an approximation treatment for many-elextron systems. Phys. Rev. 1934, 46, 618-622. [CrossRef]

97. Dunning, T.H., Jr. Gaussian basis sets for use in correlated molecular calculations. I. The atoms boron through neon and hydrogen. J. Chem. Phys. 1989, 90, 1007-1023. [CrossRef] 
98. Kendall, R.A.; Dunning, T.H., Jr.; Harrison, R.J. Electron affinities of the first-row atoms revisited. Systematic basis sets and wavefunctions. J. Chem. Phys. 1992, 96, 6796-6806. [CrossRef]

99. Boys, S.F.; Bernardi, F. The calculation of small molecular interactions by the differences of separate total energies. Some procedures with reduced errors. Mol. Phys. 1970, 19, 553-556. [CrossRef] 